Ks. Bogdan Stanaszek

Uniwersytet Papieski Jana Pawła II w Krakowie

\title{
Represje władz komunistycznych wobec radomskiego proboszcza ks. Jana Wiącka
}

Celem niniejszego artykułu jest przedstawienie represji stosowanych przez władze komunistyczne wobec ks. dra Jana Wiącka w okresie jego pracy duszpasterskiej w Radomiu. Autor zamierza ukazać, jakie były powody i formy tych represji. Temat był już częściowo poruszany ${ }^{1}$, jednak nowe, niewykorzystane dotąd materiały archiwalne pozwalają na całościowe naświetlenie tego problemu.

Latem 1941 r. ks. Jan Wiącek został proboszczem parafii NSJ w Radomiu na Glinicach (nominacja 10 lipca, objęcie placówki 27 lipca)². Liczył wówczas 41 lat życia, miał stopień doktora prawa kanonicznego, który uzyskał w 1930 r. w Katolickim Uniwersytecie Lubelskim. Doświadczenie duszpasterskie, jakie zdobył w ciągu 20 lat kapłaństwa, wiązało się głównie z pracą na stanowisku etatowego prefekta w szkołach podstawowych

1. Postać ks. Wiącka przewijała się w publikacjach dotyczących diecezji sandomierskiej: B. Stanaszek, Konflikty władz wyznaniowych z biskupem sandomierskim o obsadę parafii radomskich w latach 1953-1956, "Studia Diecezji Radomskiej" 6 (2004), s. 483-512; B. Stanaszek, Diecezja sandomierska w powojennej rzeczywistości politycznej 1945-1967, t. 1, Problematyka personalno-organizacyjna, Sandomierz 2006. Charakter popularnonaukowy miał tekst: B. Stanaszek, "Kolega" prymasa Wyszyńskiego. Ks. Jan Wiacek (19oo-1973), "Nasz Dziennik" 2008 nr 34 (2051), s. 23-25. Zupełnie nieudaną i niefachowa próbą przedstawienia działalności ks. Wiącka była książka Wspomniene o księdzu kanoniku doktorze Janie Wiącku Proboszczu Parafii pw. św. Floriana w Koprzywnicy w latach 1954-1973, Koprzywnica 2004.

2. Archiwum Diecezjalne w Sandomierzu [dalej: ADS], Akta personalne księdza [dalej: Apk.] J. Wiącka, Nominacja na proboszcza z 4 VII 1941; Pismo bpa Lorka do ks. Wiącka z 7 VII 1941; List ks. W. Kosińskiego do Kurii, bd., wpł. 7 VIII 1941; Archiwum Parafii NSJ w Radomiu [dalej: APNSJ], Kronika parafialna 1921-1987, s. 25.

Ks. Bogdan Stanaszek, Represje władz komunistycznych... 
i średnich. Na ostatniej placówce w Solcu nad Wisłą, pełniąc równocześnie obowiązki rektora kościoła poreformackiego pw. św. Stanisława, kierował remontem tej siedemnastowiecznej, chylącej się ku ruinie świątyni³ ${ }^{3}$ Doświadczenie to miało się okazać szczególnie cenne w Radomiu-Glinicach, gdzie trwała budowa kościoła parafialnego.

Sam Radom nie był dla ks. Wiącka miejscem obcym. Wcześniej bowiem (rok szkolny 1930/1931) pracował tu jako prefekt szkół powszechnych, choć zapewne okresu tego nie wspominał najlepiej ze względu na kłopoty z uzyskaniem etatu, co skutkowało problemami materialnymi i mieszkaniowymi ${ }^{4}$. Zanim zdecydował się na przyjęcie stanowiska proboszcza na Glinicach, odwiedził parafię, by zorientować się w sytuacji. Wiedział, że czeka go "ogromna praca w warunkach bardzo ciężkich"5.

Parafia NSJ w Radomiu, w dzielnicy Glinice, została utworzona 28 kwietnia $1921 \mathrm{r}^{6}$ Budowę nowego kościoła prowadził ks. dr Stanisław Gąbiński (proboszcz parafii od 18 października 1930 do 15 lipca 1940 r.)ํ. Do

3. Jan Wiącek urodził się 24 VI 1900 w Trzciance, parafia Niekrasów. Był synem Pawła i Zofii z domu Podsiadło. Do szkoły podstawowej uczęszczał w Ossali i Tursku Wielkim. W 1915 r. na podstawie egzaminu został przyjęty do I klasy gimnazjum w Sandomierzu. W 1921, po ukończeniu szóstej klasy, wstąpił do seminarium duchownego w Sandomierzu. Tu ukończył VII i VIII klasę gimnazjum, a przez kolejne cztery lata studiował filozofię i teologię. Studia ukończył z wynikiem ogólnym dobrym. Święceń diakonatu (12 IV 1927) udzielił mu bp Marian Ryx, ordynariusz sandomierski, a święceń kapłańskich (29 V 1927) bp Paweł Kubicki, sufragan sandomierski. W czasie wakacji zastępował kapelana w Zakładzie Sióstr NMP Miłosierdzia przy ul. Kozienickiej $29 \mathrm{w}$ Radomiu i proboszcza w parafii Lasocin. 28 IX 1927 został skierowany na studia na Wydziale Prawa Kanonicznego Katolickiego Uniwersytetu Lubelskiego. W $1930 \mathrm{r}$. uzyskał doktorat na podstawie pracy $\mathrm{Wy}_{\mathrm{y}}$ bór papieża na podstawie kodeksu prawa kanonicznego, której promotorem był Jan Roth (dyplom z 24 VI 1930). Następnie pracował jako etatowy prefekt szkół powszechnych w Radomiu (od 1 IX 1930), Państwowego Seminarium Nauczycielskiego w Ostrowcu Świętokrzyskim (od 1 IX 1931), a po reorganizacji szkolnictwa w siedmioklasowej Szkole Powszechnej i Państwowym Gimnazjum im. J. Chreptowicza w Ostrowcu (1937/1938). W związku z problemami z utrzymaniem etatu szkolnego w Ostrowcu 1 IX 1938 został prefektem Gimnazjum i Liceum Pedagogicznego w Solcu nad Wisłą. 3 VI 1940 otrzymał nominację na wikariusza w Solcu. ADS, Apk. J. Wiącka, passim.

4. Archiwum Katedry pw. Opieki NMP w Radomiu, Kronika parafii katedralnej Opieki NMP w Radomiu 1938-1988, s. 173.

5. $\quad$ ADS, Apk. J. Wiącka, Pismo ks. Wiącka do bpa Lorka z 3 VII 1941.

6. ADS, Akta kościoła parafialnego [dalej: Akp.] św. Jana w Radomiu 1845-1929, Dekret bpa M. Ryxa z 28 IV 1921; S. Kowalik, Fabrica ecclesiae. Żywot i sprawy radomskiego proboszcza ks. Piotra Górskiego (1843-1930), Radom 2016, s. 128.

7. B. Stanaszek, Księża diecezji sandomierskiej więzieni przez władze komunistyczne po II wojnie światowej, Rzeszów 2008, s. 73-83; http://www.nsj.radom.pl/historia. html [13.07.2016]. 
wybuchu wojny prace były bardzo zaawansowane („front, boczne nawy i zakrystia z dachem pokrytym papą, wieże wyprowadzone ponad przyszły dach nawy głównej, reszta ścian wyprowadzona jest ponad wysokość naw bocznych, a ściany nawy głównej obejmuja już i górne okna") ${ }^{8}$. Następca ks. Głąbińskiego ks. dr Bolesław Strzelecki (objął parafię od 29 sierpnia 1940 r. $)^{9}$ nie zdążył podjąć prac budowlanych, gdyż 7 stycznia 1941 r. został aresztowany przez Niemców, a następnie 5 kwietnia $1941 \mathrm{r}$. wywieziony do obozu koncentracyjnego w Oświęcimu, gdzie zmarł 2 maja 1941 tego roku. ${ }^{10}$

Przybycie ks. Wiącka na nową placówkę do Radomia odbyło się zatem w okolicznościach dość dramatycznych, nowy duszpasterz musiał osobiście odczuwać zagrożenie ${ }^{11}$. Jak już wspomniano, w Glinicach zastał sytuację bardzo trudną. Służbę Bożą sprawowano w prowizorycznej, zaniedbanej kaplicy. Parafia posiadała jednak zaplecze niezbędne do funkcjonowania - plebanię, świetlicę i budynki gospodarcze ${ }^{12}$. Oprócz proboszcza w parafii pracowali dwaj wikariusze i dwaj etatowi prefekci zatrudnieni w szkołach ${ }^{13}$.

Kiedy okazało się, że kontynuowanie budowy kościoła jest niemożliwe, nowy proboszcz zajął się doraźnymi remontami. Wspierał też działania charytatywne podejmowane przez Polski Komitet Opiekuńczy. Dzięki temu zorganizowano dwa ośrodki dożywiania: kuchnię przy ul. Słowackiego 17 dla biednych (wydawała obiady dla 750 osób) oraz ochronkę dla 120 dzieci przy ul. Kościelnej $3^{14}$. Mimo niesprzyjających warunków wojennych pod koniec 1943 r. ks. Wiącek zamówił dziesięciogłosowe organy do

8. ADS, Akp. SPJ, Protokół zdawczo odbiorczy z 29 VIII 1940; Inwentarz fundi instructi zatwierdzony 21 VIII 1941.

9. ADS, Akp. SPJ, Protokół zdawczo odbiorczy z 29 VIII 1940; Uwagi ks. B. Strzeleckiego do protokołu zdawczo-odbiorczego z 28 IX 1940.

10. S. Makarewicz, Mistrzowie wiary. Błogosławieni męczennicy radomscy z grona 108 męczenników za wiarę z okresu drugiej wojny światowej, Sandomierz 2001, s. 75-86. Papież Jan Paweł II 13 VI 1999 zaliczył go do grona błogosławionych 108 męczenników drugiej wojny światowej. ADS, Akp. SPJ, Protokół zdawczo-odbiorczy z 27 VII 1941.

11. ADS, Apk. J. Wiącka, Kazanie wygłoszone w Koprzywnicy 28 V 1967 z racji 40-lecia kapłaństwa ks. Wiącka, s. 7.

12. ADS, Akp. SPJ, Protokół zdawczo odbiorczy z 29 VIII 1940; Inwentarz fundi instructi zatwierdzony 21 VIII 1941.

13. ADS, Akp. SPJ, List ks. J. Wiącka do kurii z 31 XII 1941; APNSJ, Kronika parafialna 1921-1987, s. 35-36.

14. ADS, Akp. SPJ, List ks. J. Wiącka do kurii z 31 XII 1941; APNSJ, Kronika parafialna 1921-1987, s. $35-36$. 
kaplicy ${ }^{15}$. Założono też nową instalację elektryczną, pomalowano wnętrze, pozłocono cztery ołtarze, wprawiono dębową posadzkę. Ponadto powiększono i wyremontowano zabudowania gospodarcze, ogrodzono teren kościelny, odnowiono wnętrze plebanii ${ }^{16}$.

Po zakończeniu wojny głównym zajęciem proboszcza było organizowanie i nadzorowanie prac budowlanych przy kościele ${ }^{17}$. Doszło też do pierwszych zatargów z nową władzą. W 1947 r. pozbawiono go prawa głosu w wyborach do Sejmu Ustawodawczego ${ }^{18}$. Ks. Wiącek przeżywał spory stres związany z kłopotami rodzinnymi. Po latach tak opisywał te wydarzenia: „Brat mój Józef, w czasie fali aresztowań 1945 r. np. sędziów, prokuratorów, został aresztowany. Przebywał jakiś czas w areszcie śledczym. 20 marca 1946 r. władze śledcze wypuściły go na wolność. Potrzebował pomocy lekarskiej i zgłosił się do szpitala miejskiego w Radomiu. Tu przebywał z przerwami przez jakiś czas. Mieszkał z przerwami i u mnie na plebanii. Przez cały czas pobytu na plebanii był meldowany w biurze meldunkowym. Wyjechał później do stałego swego mieszkania: wieś Trzcianka, gmina Tursko, pow. Sandomierski. Na skutek fałszywego donosu oszczercy, został znów aresztowany. Stanął przed Sądem Okręgowym radomskim, na sesji wyjazdowej w Sandomierzu w dniu 16 marca 1948 r. Z postawionych mu zarzutów z czasów okupacji hitlerowskiej został całkowicie uniewinniony i wypuszczony na wolność. W instancji odwoławczej został również całkowicie uniewinniony przez Sąd Najwyższy w Lublinie w dniu 27 lipca 1948 r."19

Po latach represjonowani bracia Stanisław i Józef Wiąckowie podkreślali, że ks. Jan nie szczędził zabiegów w ich obronie. Bez względu na wielkie trudności odwiedzał ich wielokrotnie w więzieniach w Sandomierzu, Kielcach, Rawiczu i Sztumie. Organizował też obronę, interweniował u posłów, w prokuraturach, sądach wojskowych, u „przewodniczącego Krajowej Rady Narodowej Bolesława Bieruta, a nawet u samego Józefa Stalina"20.

15. ADS, Akp. SPJ, List ks. J. Wiącka do bpa Lorka z 11 III 1944; Odpowiedź z 15 III 1946; APNSJ, Kronika parafialna 1921-1987, s. 27.

16. APNSJ, Kronika parafialna 1921-1987, s. 27.

17. ADS, Apk. J. Wiącka, List ks. Wiącka do bpa Lorka, wpł. 27 XII 1946 i odpowiedź bpa Lorka.

18. ADS, Apk. J. Wiącka, Kazanie wygłoszone w Koprzywnicy 28 V 1967 z racji 40-lecia kapłaństwa ks. Wiącka, s. 15.

19. ADS, Apk. J. Wiącka, List ks. J. Wiącka do UdSW z 26 VIII 1953.

20. ADS, Apk. J. Wiącka, List Stanisława, Józefa i Antoniego Wiącków do kurii z 7 V 1973 . 
21 lutego 1949 r. proboszcz parafii NSJ został dziekanem nowo utworzonego dekanatu Radom-Południe ${ }^{21}$. Nie chciał przyjąć tej nominacji, gdyż obawiał się, że będzie mu trudno pogodzić te obowiązki z budową kościoła. Stwierdzał, że warunki pogarszały się „z każdym niemal tygodniem i miesiącem". Skarżył się również na częste problemy zdrowotne, wspomniał o kłopotach rodzinnych, które "trapią i denerwują" (niewątpliwie chodziło o represjonowanych braci). Prosił biskupa, by traktował jego funkcję dziekańską jako „coś chwilowego, przejściowego"22.

$\mathrm{Na}$ to, by ordynariusz zrezygnował z angażowania ks. Wiącka do ważnych zadań, jednak się nie zanosiło. Wręcz przeciwnie, zbliżał się czas, kiedy miał mu zlecić nowe, odpowiedzialne obowiązki, choć sam zainteresowany nie palił się do ich podjęcia ${ }^{23} .7$ października 1949 r. ks. Jan Wiącek został mianowany proboszczem eksponowanej parafii Opieki NMP w Radomiu (dzisiejsza katedra) ${ }^{24}$.

Owoce ośmioletniej pracy w parafii NSJ na Glinicach, w niesprzyjających warunkach, były godne uznania. Zostawiał mury kościoła nakryte dachem. Ukończono też budowę sklepień, wykonano część tynków wewnętrznych, zaszklono sześć okien w górnej kondygnacji kościoła. Wykończono też fasadę, która była bardzo kosztowna, wieżę podciągnięto do wysokości $30 \mathrm{~m}$. Na parafii nie ciążyły żadne długi. Pozostały też materiały o wartości ponad 3 mln zł (zgromadzone cegły miały wystarczyć na dokończenie wieży) ${ }^{25}$. Dzięki kontynuowaniu prac przez ks. Adama Łukaszewicza 10 grudnia 1950 r. bp Jan Lorek poświęcił nową świątynię ${ }^{26}$.

Jak już wspomniano, 7 października 1949 r. ks. Jan Wiącek został mianowany proboszczem parafii Opieki NMP w Radomiu ${ }^{27}$. Obejmując nowe stanowisko, miał 49 lat życia i 23 lata kapłaństwa. Został proboszczem największej parafii w mieście, posiadającej okazałą, neogotycką świątynię wzniesioną w latach 1899-1908 (parafia została erygowana w 1921 r.) ${ }^{28}$. Placówka, którą obejmował, była uważana za najbardziej eksponowaną

21. ADS, Apk. J. Wiącka, Nominacja z 21 II 1949.

22. ADS, Apk. J. Wiącka, Pismo ks. Wiącka do bpa Lorka z 28 II 1949.

23. ADS, Apk. J. Wiącka, Kazanie wygłoszone w Koprzywnicy 28 V 1967 z racji 40-lecia kapłaństwa ks. Wiącka, s. 11.

24. ADS, Apk. J. Wiącka, Nominacja z 7 X 1949.

25. ADS, Akp. SPJ, Protokół zdawczo odbiorczy z 22 X 1949, załącznik nr 1.

26. APNSJ, Kronika parafialna 1921-1987, s. 39.

27. ADS, Apk. J. Wiącka, Nominacja z 7 X 1949.

28. S. Kowalik, Fabrica ecclesiae..., dz. cyt., s. 75-95, 125-128. 
w diecezji sandomierskiej. Okazało się jednak, że nowy proboszcz będzie się musiał zmierzyć z licznymi poważnymi wyzwaniami. Już w protokole objęcia parafii odnotowano znaczne długi obciążające parafię, powstałe przed wojną, m.in. z racji zakupu domu przy ul. Sienkiewicza 13 przeznaczonego na plebanię ${ }^{29}$.

Jeszcze większy problem miała stanowić zagęszczająca się atmosfera polityczna i narastająca nagonka na Kościół. W liście do bpa Lorka z 10 listopada 1949 r. pisał o kłopotach związanych z uregulowaniem przedwojennych długów parafii. Wspomniał też, że ks. Bojarczak został znów wezwany „w znanych celach do Bezp[ieczeństwa] Publ[icznego]"30.

Atmosferę nagonki dawało się odczuć w Radomiu już od dłuższego czasu. W związku z wydaniem dekretu o ochronie wolności sumienia i wyznania (5 sierpnia 1949 r.) proboszczów radomskich wezwano na rozmowy z prezydentem miasta. Akcja miała charakter ogólnopolski, rozmowy prowadzono w starostwach powiatowych, a ich celem było zastraszenie i sondowanie nastrojów księży, by wyróżnić wśród nich „wrogich”, "pozytywnych", "biernych", co miało ułatwić akcję "dezintegracji duchowieństwa"31. Ks. Wiącek został wezwany na rozmowę jeszcze jako proboszcz parafii NSJ na Glinicach (9 sierpnia 1949 r.). Z protokołu, który sporządzono przy tej okazji, możemy wnioskować, że duchowny starał się tak wypowiadać, by nie wchodzić w otwarty konflikt z władzami świeckimi. Jednocześnie podkreślał swoją wierność przepisom kościelnym. Miał stwierdzić, że będzie przeciwdziałał sektom szerzonym za pieniądze amerykańskie (ukłon w stronę władz), a „chyba to nie będzie przeciw dekretowi". Odnotowano też jego wypowiedź: „jeśli komunista poprosi sam o posługi religijne, nie odmówi mu żaden ksiądz, chyba żeby on nie chciał, tylko sama rodzina"32.

Władze, niezbyt chyba zadowolone z wyników sondażowej rozmowy, starały się "zmiękczyć" ks. Wiącka, stosując wobec niego politykę ciągłego

29. ADS, Akp. ONMPR (1949-1989), Protokół zdawczo-odbiorczy z 24 X 1949.

30. ADS, Akp. ONMPR (1949-1989), List ks. J. Wiącka do bpa Lorka z 10 XI 1949. Chodziło o ks. Mariana Bojarczaka, proboszcza z Wierzbicy, podejrzewanego przez UB o wspieranie niepodległościowego podziemia. Funkcjonariusze podejmowali próby werbunku. Por. B. Stanaszek, J. Nowakowski, Słownik biograficzny księży diecezji sandomierskiej $X I X-X X$ w., t. 1, Sandomierz 2014, s. 72-73; B. Stanaszek, Diecezja..., dz. cyt., t. 1, s. 166.

31. B. Stanaszek, Diecezja..., dz. cyt., t. 1, s. 185-186.

32. Archiwum Akt Nowych w Warszawie [dalej: AAN], Ministerstwo Administracji Publicznej, sygn. 959, s. 4-12, Protokół rozmów prezydenta miasta Radomia Wieczorka z księżmi w dn. 8-9 VIII 1949. 
nękania. Rozpoczęto od przepychanek związanych z plebanią. Jeszcze za poprzedniego proboszcza ks. prał. dra Henryka Gierycza Wojewódzka Komisja Lokalowa w Kielcach usiłowała dokwaterować na plebanię lokatorów (styczeń 1949 r.). Wówczas Kuria Diecezjalna w Sandomierzu wydała zaświadczenie, że mieszkanie nr 3/4 przy ul. Sienkiewicza 13, obejmujące pięć pokoi, służy biskupowi sandomierskiemu i jego kapelanowi w czasie pobytów w Radomiu; mieści się tam również filia Sądu Biskupiego w Sandomie$\mathrm{rzu}^{33}$. Nie zakończyło to jednak sprawy, a naciskany w tej kwestii miał być nowy proboszcz ks. Wiącek.

28 sierpnia 1950 r. Oddział Kwaterunkowy Prezydium Miejskiej Rady Narodowej w Radomiu wydał decyzję o przydzieleniu Zarządowi Okręgowemu Caritas lokalu przy ul. Sienkiewicza 13, składającego się z pięciu pokoi ${ }^{34}$. W tym wypadku nie chodziło o mieszkanie proboszcza, ale o pomieszczenia na drugim piętrze plebanii, które zajmowało przedszkole prowadzone przez siostry zmartwychwstanki. Przedszkole uruchomiono tam w 1945 r. z inicjatywy ks. Dominika Ściskały. On również zaprosił do Radomia siostry zmartwychwstanki, które objęły placówkę. Parafia zachowała prawo własności i ponosiła koszty związane z konserwacją budynku. W połowie sierpnia 1950 r. zakończono remont dachu. Proboszcz kwestionował zasadność decyzji Oddziału Kwaterunkowego i wskazywał, że została wydana z naruszeniem przepisów prawnych ${ }^{35}$. Jednak Wojewódzka Komisja Lokalowa w Kielcach 3 listopada 1950 r. podtrzymała wcześniejszy nakaz kwaterunku ${ }^{36}$. Sprawa trafiła następnie do Urzędu do Spraw Wyznań. W odwołaniu kurii wskazano, że siostry zmartwychwstanki posiadały ważne uprawnienia do prowadzenia przedszkola, a Wojewódzka Komisja Lokalowa przekroczyła swoje uprawnienia, próbując relegować je z budynku kościelnego ${ }^{37}$. Ostatecznie przedszkole zachowało swój lokal, ale ceną za to było podporządkowanie się przez siostry zarządowi

33. ADS, Akp. ONMPR (1949-1989), List Kurii Diecezjalnej do Wojewódzkiej Komisji Lokalowej w Kielcach ze I 1949.

34. ADS, Akp. ONMPR (1949-1989), Odpis decyzji Prezydium MRN w Radomiu z 28 VIII 1950.

35. ADS, Akp. ONMPR (1949-1989), List ks. Wiącka do Prezydium MRN w Radomiu z 30 VIII 1950.

36. ADS, Akp. ONMPR (1949-1989), Orzeczenie z 3 XI 1950.

37. ADS, Akp. ONMPR (1949-1989), Pismo Kurii Diecezjalnej do min. A. Bidy z 29 XI 1950 . 
upaństwowionego Caritasu ${ }^{38}$. Tak więc w danej chwili do przejścia lokalu nie doszło, ale władze nie zamierzały rezygnować z ingerowania w sprawy wewnętrzne Kościoła.

Z końcem marca 1953 r. ks. Wiącek wysłał do Ministerstwa Gospodarki Komunalnej odwołanie od decyzji Referatu Mieszkaniowego Prezydium MRN w Radomiu z 24 marca 1953 r. Był w niej nakaz dokwaterowania w ciągu 14 dni sióstr zmartwychwstanek zamieszkałych w Radomiu przy ul. Rokosznego 3 do domu parafialnego przy ul Sienkiewicza 13. Proboszcz skarżył się, że naruszano w ten sposób przepisy prawne i procedurę. Zwrócił uwagę, że w budynku parafialnym mieszka ośmiu księży (wikariusze: K. Dunikowski, S. Maliński, A. Gołembski, A. Porębski, rezydent i spowiednik Wł. Dziubek oraz prefekci: B. Szymański i dr Wł. Sedlak oraz artysta malarz mgr Wł. Paciak, który ukończył Akademię Sztuk Pięknych w Krakowie) - każdy z nich korzystał z jednego pokoju. Proboszcz dysponował większym mieszkaniem (sypialnia, pokój stołowy, kuchnia i pokój dla pomocy domowej). Ks. Wiącek przywoływał jednak argumenty, które nawet w myśl bezdusznego prawa stworzonego przez komunistów uzasadniały korzystanie z większej liczby pokoi. Wskazywał, że zarówno proboszcz, jak i kucharka mają zaświadczenia, iż z racji na stan zdrowia przysługuje im dodatkowe pomieszczenie. Pisał, że pokoje są konieczne dla gości, którzy służbowo przyjeżdżają do Radomia (księża i biskup ordynariusz). Na plebanii mieściło się również biuro ekspozytury Sądu Biskupiego w Sandomierzu. Parafia była siedzibą dziekana, odbywały się tam konferencje duszpasterskie, rekolekcje dla 40 księży z obydwu dekanatów radomskich. Oceniał, że żądanie dokwaterowania 27 osób (w tym 11 sióstr) oraz przygotowanie lokali dla kolejnych 16 osób jest niewykonalne. Mimo deklarowanych "najszczerszych chęci" nie widział możliwości spełnienia tych wymagań. I tym razem wykonanie decyzji zostało wstrzymane (16 kwietnia 1953 r. $)^{39}$.

Nie były to jedyne zakusy władz na własność kościelną. 30 sierpnia 1950 r. ks. Wiącek informował biskupa o problemach związanych z siedzibą Towarzystwa Dobroczynnego w Radomiu. W budynku położonym przy

38. B. Stanaszek, Diecezja..., dz. cyt., t. 1, s. 325-326. Caritas nie ponosił żadnych kosztów związanych z utrzymaniem lokalu przedszkola. ADS, Apk. J. Wiącka, Pismo ks. Wiącka bez adresata z 17 XI 1953.

39. ADS, Akp. ONMPR (1949-1989), Pismo ks. Wiącka do Ministerstwa Gospodarki Komunalnej z 28 III 1953. 
ul. Siennej, w najbiedniejszej dzielnicy, "wśród ruder i baraków", mieściło się przedszkole prowadzone przez siostry szarytki. W sąsiedztwie staraniem sióstr wybudowano ze składek publicznych barak, w którym mieściła się kaplica. Kiedy szarytki wycofały się z tej placówki, przejęły ją siostry michalitki, jednak władze państwowe zlikwidowały Towarzystwo Dobroczynne i przedszkole przejęto pod zarząd magistratu. Próbowano również zająć barak, ale uniemożliwiła to stanowcza postawa ludności. W każdą niedzielę w kaplicy odprawiano msze święte, a w maju i październiku nabożeństwa popołudniowe ${ }^{40}$. Latem 1950 r. pomoc w odnowieniu wnętrza kaplicy deklarował zarząd upaństwowionego Caritasu. Propozycja miała jednak podtekst polityczny - chodziło o podporządkowanie kolejnych placówek organizacji wykorzystywanej do dezintegracji Kościoła. Ks. Wiącek interweniował u przełożonej sióstr michalitek. Przypominał, że parafia wyremontowała ostatnio dach kaplicy. Podkreślał, że dopuszczenie do prac innych osób i organizacji bez zgody proboszcza byłoby bezprawiem i wkroczeniem w kompetencje władz kościelnych. Prosił siostry o dalszą opiekę nad kaplicą ${ }^{41}$.

Ważnym instrumentem wykorzystywanym do utrudnienia życia duchownym były podatki. Arbitralne decyzje urzędników mogły boleśnie uderzać w poszczególne osoby i instytucje. Jedna z szykan polegała na wyznaczaniu podatku od tzw. wzbogacenia wojennego. Władze skarbowe wymierzyły go ks. Wiąckowi i ks. Wacławowi Kosińskiemu, proboszczowi parafii św. Jana w Radomiu. Obaj duchowni w 1943 r. zdecydowali się zabezpieczyć pieniądze kościelne poprzez kupno placu w miejscowości Jedlnia-Letnisko. Ponieważ nie mogli nabyć gruntu na własność parafii, zakupili go jako osoby prywatne. W 1950 r. plac został sprzedany przez ks. Kosińskiego i nowego proboszcza z Glinic. 40 proc. uzyskanej sumy (taki wkład wniósł w zakup ks. Wiącek) zostało obrócone na potrzeby kościoła NSJ na Glinicach (pieniądze podjął ks. Łukaszewicz). Natomiast podatek został wymierzony przez władze skarbowe ks. Wiąckowi ${ }^{42}$.

40. ADS, Akp. ONMPR (1949-1989), List ks. Wiącka do bpa Lorka z 30 VIII 1950.

41. ADS, Akp. ONMPR (1949-1989), List ks. Wiącka do przełożonej sióstr michalitek z 29 VIII 1950.

42. ADS, Akp. ONMPR (1949-1989), Pismo ks. Wiącka do bpa Lorka z 30 V 1952; Akp. SPJ, Protokół zdawczo-odbiorczy parafii z 22 X 1949; APNSJ, Kronika parafialna 1921-1987, s. 28-29. W kronice zanotowano, że parcela i część domu w Jedlni-Letnisku po wojnie miała wartość 300 tys. zł

Ks. Bogdan Stanaszek, Represje władz komunistycznych... 
Jedną z poważnych trosk ks. Wiącka stanowiły długi ciążące na parafii. Do połowy stycznia 1950 r. udało się wypłacić wierzycielom 1 mln 800 tys. zł. Nie obeszło się jednak bez działań urzędu skarbowego - przedwojenny dług hipoteczny wobec rodziny Lamparskich (45 tys. zł) został pomnożony 30 razy, a parafia otrzymała nakaz płatniczy podatku na $1 \mathrm{mln}$ 300 tys. zł. Proboszcz zamierzał spłacić tę sumę do 1 maja 1950 r. ${ }^{43}$

Można powiedzieć, że ks. Wiącek miał dobrą intuicję, która pozwalała uniknąć zagrożeń nieodległej przyszłości. Inflacja drenowała gospodarkę, a 28 października 1950 r. władze przeprowadziły wymianę pieniędzy. Przelicznik dla płac i cen wynosił 3 nowe złote za 100 starych. Oszczędności w PKO wymieniano na tej zasadzie do 100 tys. zł. Natomiast gotówkę wymieniano w relacji 1 nowy zł za 100 starych. Faktycznie więc ludzie tracili 2/3 zgromadzonych oszczędności. Nie odnotowano jednak protestów, gdyż wszechobecny terror paraliżował je w zarodku ${ }^{44}$.

W lutym $1951 \mathrm{r}$. w raporcie przesłanym kurii ks. Wiącek potwierdzał, że udało mu się spłacić stare zadłużenie, choć wymagało to wielu zabiegów, starań i pochłaniało dużo energii ${ }^{45}$. Nie oznaczało to jednak końca kłopotów materialnych. Wręcz przeciwnie, polityka fiskalna stawała się coraz bardziej dokuczliwa. W kwietniu 1952 r. ks. Wiącek bardzo obszernie informował kurię o szykanach finansowych, których doznawał. Właściwie doświadczał ich od dwóch lat, co zbiegło się ze zmianą kierownictwa Wydziału Finansowego Prezydium MRN w Radomiu. Wymiar podatków w odniesieniu do niektórych księży przybrał wówczas „charakter anormalny". Proboszcz relacjonował: „W ubiegłym roku [1951 - BS], na początku lutego otrzymałem nakaz płatniczy na zapłacenie domiaru za rok 1949 - 8500 zł. Powołując się na ustawę podatkową poprosiłem o uzasadnienie tego podatku. Z uzasadnienia wynikało, że Księgi podatkowej nr 11 nie wzięto pod uwagę, gdyż brak w niej wpisanej tacy za miesiące VIII, IX, X, XI i XII 1949 r., choć przecież wiadomo, że obowiązek wpisywania tacy istnieje dopiero od 1 I 1950 r.". W uzasadnieniu podano również błędnie, że przez cały 1949 r. ks. Wiącek zajmował stanowisko proboszcza parafii Opieki NMP (tymczasem objął ją w październiku 1949 r.). Proboszcz pisał: „wzięto dowolna liczbę parafian, pomnożono przez dowolną liczbę i wyszła olbrzymia

43. ADS, Akp. ONMPR (1949-1989), List ks. Wiącka do bpa Lorka z 17 I 1950.

44. A. L. Sowa, Od Drugiej do Trzeciej Rzeczypospolitej (1945-2001), Kraków 2001, s. 118.

45. ADS, Akp. ONMPR (1949-1989), Pismo ks. Wiącka do kurii z 6 II 1951. 
suma do zapłacenia". Odwołania okazały się nieskuteczne (w województwie tylko nieznacznie obniżono wymiar podatku). Urzędnicy wywierali natomiast presję i sugerowali, że określone zachowania duchownego mogą skutkować obniżeniem wymiaru podatkowego. Naciskano, by uczestniczył w spotkaniach tzw. księży patriotów. W liście czytamy: „Kierownik Wydziału Finansowego sam osobiście zapraszał mnie na zebranie księży w Radomiu, ofiarując mi przewodnictwo na tymże zebraniu. Po niejakim czasie urzędnicy Wydziału Finansowego, którzy wymierzają podatki znów mnie odwiedzili, zapraszając na zjazd do Kielc - niezależnie od zaproszenia piśmiennego, które wcześniej otrzymałem. Na ostatni zjazd we Wrocławiu dla odmiany zapraszał prokurator i to o godzinie dość późnej wieczór". W końcu kierownik radomskiego Wydziału Finansowego wezwał proboszcza i postawi trzy warunki. Żądał likwidacji placówki sióstr zmartwychwstanek na Młodzianowie (lokal potrzebny dla Caritasu), oddelegowania jednego księdza do pracy w Caritasie i zmiany stanowiska proboszcza "do całości spraw". Ks. Wiącek bronił się i argumentował, że przydzielanie księży do Caritasu nie leży w jego kompetencjach. Podkreślał, że sam nie zwalcza obecnego ustroju, a ograniczył się jedynie do pracy ściśle duszpasterskiej. Relacjonował: „W roku ubiegłym inni księża nie otrzymywali tak wysokich podatków. Dwóch przebywało w więzieniu [ks. W. Kosiński i ks. A. Łukasik - BS] ${ }^{46}$, a trzeci otrzymał mały domiar w par[arafii] Kuczki. Rok bieżący przyniósł nam znów nowe niespodzianki. Ks[iądz] proboszcz par[afii] Fara [miał zapłacić] przeszło 13000 zł, mariacki -12 320 zł, Glinice przeszło 10000 zł, wikariusze 2200 zł. Poprosiliśmy znów o uzasadnienie tak wysokich domiarów. Uzasadnienie dotąd nie nadeszło. Tymczasem w piątek urzędnicy skarbowi złożyli mi kolejno wizyty. Powoływali się na to, że plan nie wykonany, że brak do tego znacznych sum, że grożą wszystkim urzędnikom przykre konsekwencje, że oni są dobrymi Polakami - katolikami, proszą o kilka tysięcy a conto tych wymierzonych domiarów na rok 1950. Ks. dziekan Kosiński wyjął 1500 zł i dał im. Ks. Łukasiewicz

46. ADS, Apk. J. Wiącka, Pismo ks. J. Wiącka do bpa Lorka, bd., wpł. do kurii 10 IV 1952. Ks. Wacław Kosiński, proboszcz parafii św. Jana w Radomiu, został aresztowany przez UB 22 X 1950; zwolniono go przed 14 III 1951. Represje miały związek z jego wypowiedziami cytowanymi w prasie niemieckiej w czasie okupacji o zamordowaniu polskich oficerów w Katyniu przez wojska ZSRR. Ks. Andrzej Łukasik, proboszcz parafii św. Teresy, w więzieniu przebywał od 14 VI 1950 do 28 VIII 1951. Aresztowanie miało związek z nielegalną organizacją młodzieżową Orzeł Biały. B. Stanaszek, Księża diecezji..., dz. cyt., s. 64-68, 127-133. 
wystawił czek do banku na pieniądze kościelne na sumę 3000, ja w formie mocnej i stanowczej zrobiłem im najpierw wykład, że takie metody i sposoby podchodzenia do płatnika są niedopuszczalne. Grozili surowymi konsekwencjami. Odpowiedziałem, że na to jestem zupełnie przygotowany, ale takiej sumy nie zapłacę, gdyż to przekracza moje możliwości płatnicze. Zaapelowali wówczas do miłosierdzia i łaski płatnika: «co łaska, bo nas czekają przykre następstwa». Wyjąłem wówczas z biurka 300 zł i z portfela 150 zł, razem 450 zł i dałem im, pokwitowali". Ks. Wiącek pisał: "Żaden z nas o własnych siłach w tym terminie, jaki władze skarbowe wyznaczą, nie jest w stanie tych sum zapłacić. Społeczeństwo zubożałe i wyczerpane składa z racji posług religijnych stosunkowo małe ofiary, które są dzielone między wszystkich pracowników kościelnych. Proporcja między podatkiem księdza proboszcza a księdza wikarego niewspółmierna. Odwołanie się do wyższych instancji chybia celu". Oceniał, że urzędnicy wręcz „molestują płatnika", przysyłają urgensy, kolejne domiary, grożą nawet pozbawieniem wolności z racji „sabotażu".47.

Mimo szykan ze strony władz państwowych i niesprzyjających warunków pracy ks. Wiącek starał się owocnie prowadzić działalność duszpasterską. Wspomagali go w tym wikariusze, ale i na nich spadały różne represje. W połowie stycznia $1950 \mathrm{r}$. władze oświatowe bez podania przyczyny zwolniły ze szkoły ks. A. Porębskiego ${ }^{48}$.

Ks. Wiącek wiele troski poświęcał świątyni parafialnej. Starał się o uzyskanie pozwolenia na wykonanie polichromii kościoła. Uwagi do projektu przesłał Wydział Kultury Prezydium Wojewódzkiej Rady Narodowej w Kielcach (23 maja 1952 r.), opiniowała go również Diecezjalna Komisja Bu-

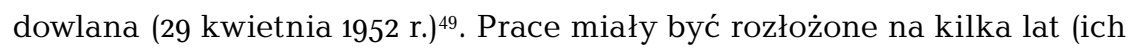
koszt, wraz z pracami remontowo-murarskimi oceniano na 340 tys. zł) $)^{50}$.

Biskup ordynariusz doceniał jego działalność. Mianował go kanonikiem honorowym kapituły katedralnej w Sandomierzu ${ }^{51}$, a 23 listopada

47. ADS, Apk. J. Wiącka, Pismo ks. J. Wiącka do bpa Lorka, bd., wpł. do kurii 10 IV 1952. Informacje otrzymane od ks. Wiącka skłoniły bpa Lorka do podjęcia interwencji w Ministerstwie Finansów. O sprawie powiadomiono też Sekretariat Episkopatu Polski. B. Stanaszek, Diecezja..., dz. cyt., t. 1, s. 399.

48. ADS, Akp. ONMPR (1949-1989), List ks. Wiącka do bpa Lorka z 17 I 1950.

49. ADS, Akp. ONMPR (1949-1989), Odpis pisma PWRN do Urzędu Parafialnego Opieki NMP w Radomiu z 23 V 1952; Pismo kurii do ks. Wiącka z 29 IV 1952.

50. ADS, Akp. ONMPR (1949-1989), Pismo ks. Wiącka do kurii z 15 IV 1952.

51. ADS, Apk. J. Wiącka, Nominacja z 23 IX 1950. 
1950 r. na czas „nieobecności ks. Kosińskiego" powierzył mu pełnienie obowiązków dziekana dekanatu radomskiego północnego (nadal był dziekanem dekanatu Radom-Południe) $)^{52}$.

Władze świeckie starały się paraliżować działania duszpasterskie.Zgodnie z wytycznymi płynącymi z Warszawy, próbowano usunąć wszelkie przejawy kultu religijnego z przestrzeni publicznej i przenieść je w obręb świątyni. Szczególnie drażniły władze procesje Bożego Ciała. Do konfliktów na tym tle doszło w 1951 r. Wniosek o zorganizowanie wspólnej procesji dla całego miasta złożyli 11 maja 1951 r. dziekani: ks. Jan Wiącek i ks. Wacław Kosiński. Procesje miały się odbyć w Boże Ciało (17 maja) oraz w oktawie: 27 i 31 maja. Prezydium MRN w Radomiu po porozumieniu z Powiatowym Urzędem Bezpieczeństwa Publicznego i KM PZPR wyznaczyło inną trasę, spychając procesję z głównych ulic miasta. Nie chciał tego zaakceptować ks. Wacław Kosiński, proboszcz parafii św. Jana. W trakcie rozmowy w Prezydium MRN odgrażał się, że "po wybojach i wertepach nie pójdzie"53. Ostatecznie jednak organizatorzy dostosowali się do decyzji władz ${ }^{54}$. Do ponownych zatargów związanych z trasą procesji doszło rok później. Z odpowiednim wyprzedzeniem (28 kwietnia 1952 r.) ks. Kosiński i ks. Wiącek zwrócili się do Prezydium MRN w Radomiu w sprawie procesji Bożego Ciała. Jednak 16 maja Prezydium MRN odmówiło wydania zgody na procesję tradycyjną trasą 12 i 19 czerwca, zaś 15 czerwca w ogóle zakazano parafii Opieki NMP organizowania corocznej procesji na Glinice. Wskazano trasę procesji po bocznych ulicach: ciasnych i wąskich. Proboszczowie argumentowali, że skierowanie dużej procesji na ul. Traugutta może zagrażać bezpieczeństwu (znajdowała się tam remiza straży pożarnej, którą w razie potrzeby nie mogłaby podjąć interwencji). Dziekani zwracali uwagę, że pochody państwowe odbywają się głównymi ulicami,

52. ADS, Apk. J. Wiącka, Pismo bpa Lorka do ks. Wiącka z 23 XI 1950. Biskup podjął taką decyzję na prośbę ks. prał. Popkiewicza, wicedziekana, i księży wspomnianego dekanatu.

53. Ks. Kosiński wypowiadał się odważnie, choć miał już za sobą kilkumiesięczny pobyt w więzieniu stalinowskim, o czym już wspominano. B. Stanaszek, Kosiński Wacław, w: Leksykon duchowieństwa represjonowanego w PRL w latach 1945-1989, t. 1. Warszawa 2002, s. 123-124.

54. AAN, UdSW, sygn. 7/5, Sprawozdanie RdSW w Kielcach za II kwartał 1951 r., S. $196-201$. 
zepchnięcie religijnych procesji na boczne wywoła komentarze o dyskryminacji Kościoła. Zabiegali o zezwolenie na procesje tradycyjną trasą ${ }^{55}$.

Represje zmierzały do zastraszenia duchowieństwa, ale przyniosły połowiczny skutek. Niewątpliwie wywołały poczucie niepewności wśród księży, jednak nie sparaliżowały działalności duszpasterskiej. Duchowni radomscy zachowywali także dystans wobec prób formowania w mieście ruchu "księży patriotów", o co zabiegali komuniści. Pierwsze publiczne zebranie „księży postępowych" w Radomiu, zresztą nieudane, odbyło się 12 grudnia 1950 r. Organizował je Polski Komitet Obrońców Pokoju w lokalu sióstr szarytek. Zaproszenia rozesłano do 42 księży świeckich i zakonnych mieszkających w Radomiu oraz do kleru z trzech sąsiednich powiatów. Jednak księża radomscy zbojkotowali spotkanie, a przybył na nie jedynie ks. Burowski, kapelan wojskowy ("człowiek bez autorytetu, który po opuszczeniu Radomia ożenił się") oraz dwóch ojców bernardynów z Radomia. Urzędnicy państwowi usiłowali wcześniej skłonić ks. Wiącka, by objął przewodnictwo podczas zebrania. Chcąc wprowadzić go w błąd, twierdzili, że na zjazd miał przybyć bp Jop, ale w ostatniej chwili udał się na takie samo zebranie do Kielc. Obiecywali "sute przyjęcie", wyglądało - relacjonował ks. Wiącek - że "traktują zebranie raczej od strony libacji i na wesoło". Podczas „obrad" jeden z księży referentów udowadniał, „że światopogląd Marksa da się zupełnie pogodzić ze światopoglądem chrześcijańskim i że na etyce Marksa wyrastają święci". Na zebranie przybył ks. Stanisław Skurski, były proboszcz ze Wszechświętych, a wówczas już jeden z czołowych działaczy Caritasu w Warszawie. Krytykował on hierarchię kościelną, biskupa Lorka, ks. Wiącka, „wymyślał im, że są reakcyjnie nastawieni i zacofani, że słuchają audycji zagranicznych, nie rozumieją obecnych czasów, na zebranie nie chcą przyjśćc. Spotkanie zakończyło się "libacją" w stołówce caritasowskiej, a jeden z "księży patriotów" „upił się do nieprzytomności". Po zjeździe ks. Wiącka wezwano do Referatu do Spraw Wyznań w Radomiu, gdzie pytano: „dlaczego z księżmi gremialnie na zjazd nie przyszedł". Odpowiedział, że zjazd miał charakter dobrowolny i był organizowany bez wiedzy i zgody władz diecezjalnych. Dodał, że „na działalność

55. ADS, Akp. ONMPR (1949-1989), Pismo ks.ks. Kosińskiego i Wiącka do PWRN w Kielcach z 24 V 1952. Wskazali oni trasę tradycyjną, która przemierzano miasto przed wojną i po wojnie. W piśmie podkreślono, że trasa ta była uzgodniona w 1945 r. z komendantem sowieckim Wołkowem, który 12 VI 1945 brał udział w głównej procesji i prowadził celebransa podtrzymując go pod rękę. 
i nastawienie sióstr zakonnych wpływu nie ma i w tych sprawach nie decyduje. Zgromadzenia zakonne mają swoich przełożonych"56.

Drugie zebranie „księży patriotów” w Radomiu odbyło się 11 października 1952 r. na plebanii mariackiej w przedszkolu prowadzonym przez siostry zmartwychwstanki pod firmą Caritasu (znajdowało się nad mieszkaniem ks. Wiącka). Ks. Skurski wraz z ks. Lempartym „nachodził plebanię, by zaprosić proboszcza, który był wówczas na spowiedzi u sióstr ${ }^{57}$.

Odrzucanie kolejnych zaproszeń i wyraźny dystans proboszcza parafii mariackiej wobec inicjatyw dezintegracyjnych lansowanych przez władze musiało budzić irytację. Widać też zmiany w postrzeganiu ks. Wiącka odnotowywane w kartotece ewidencyjnej duchownych zachowanej w Urzędzie do Spraw Wyznań. Jedna notatka zawierała następująca informację: „Wpływ na parafian znaczący (cieszy się wielkim zaufaniem i poważaniem). W kazaniach nie porusza zagadnień politycznych. Do obecnej rzeczywistości ustosunkowany pozytywnie [...]. 6 września 1950 apel pokoju podpisał". Kolejna opinia była już jednoznacznie niekorzystna: „Jest wrogiem obecnego ustroju ludowego, broni przywilejów kościoła, b[yłego] Caritasu. Jest ślepo oddany biskupowi i papieżowi"58.

Mimo zaostrzenia kursu władze państwowe nie umiały sobie poradzić z paradoksalnie rosnącymi wpływami Kościoła na społeczeństwo. Temat ten poruszono na odprawie referentów wyznaniowych w Kielcach 9 sierpnia 1952 r. Józef Balcerowski z Prezydium MRN w Radomiu charakteryzując sytuację mówił, że kler coraz lepiej "organizuje swoje imprezy", a kierują nim dziekani: Wiącek i Kosiński „znani z wrogiej działalności”. Spośród 42 księży pracujących w mieście tylko trzech określił jako "pozytywnych". Sam Radom nazwał „drugą Częstochową". Jego ocena była dość pesymistyczna, gdyż nie widział możliwości zmiany sytuacji na lepsze. Wystąpienie spotkało się z ostrą krytyką ze strony Stefana Jarosza,

56. Archiwum Sekretariatu Episkopatu Polski w Warszawie [dalej: ASEP], sygn. 100/ XVI, s. 158-170, Pismo ks. Wiącka do Kurii Diecezjalnej w Sandomierzu z 20 XII 1956; por. ADS, Apk. J. Wiącka, 26 VIII 2953, Pismo ks. Wiącka do UdSW.

57. ADS, Apk. J. Wiącka, Pismo ks. Wiącka do UdSW z 26 VIII 1953; AAN, UdSW, sygn. 56/68, Wniosek Zarządu Caritas o usunięcie ks. Wiącka, bd., s. 73; ASEP, sygn. 100/XVI, Pismo ks. J. Wicka do UdSW z 18 VIII 1953, s. 139-140, toż z 26 VIII 1953, 145-149, Pismo ks. J. Wiącka do kurii z 20 XII 1953, 158-170. We wniosku złożonym przez Zarządu Caritas w Radomiu o usunięcie ks. Wiącka czytamy: „Ks. Wiącek ma największy autorytet wśród miejscowych księży i osób duchownych".

58. AAN, UdSW, sygn. 56/68, Karta ewidencyjna nr 42, bd., s. 41, Karta ewidencyjna, bd., s. 91-92. W karcie odnotowano również wypowiedź z kazania z 8 II 1952. 
kierownika wojewódzkiego Referatu do Spraw Wyznań w Kielcach. W tej sytuacji Balcerowski zadeklarował gotowość ustąpienia ze stanowiska. Jednak władze faktycznie nie miały w danej chwili lepszego pomysłu na prowadzenie polityki wyznaniowej. Krytyka miała zmobilizować referentów do bardziej wydajnej pracy. Balcerowski pełnił więc dalej swoje obowiązki ${ }^{59}$. Bardziej konkretnych wskazówek Jarosz udzielił referentom wyznaniowym 8 października 1952 r. Powiedział wówczas, że „w Radomiu trzeba stuknąć choć jednego księdza, trzeba o tym myśleć i żyć tymi sprawami"60.

Działania w tym kierunku prowadził także Urząd Bezpieczeństwa. Funkcjonariusze PUBP w Radomiu starali się zastraszyć ks. Wiącka. Z pewnością ich "dziełem" lub pomysłem było nękanie ks. Wiącka telefonami i pogróżkami. Informacje na ten temat czerpiemy z korespondencji, którą radomski dziekan kierował do Urzędu Pocztowego w Radomiu. 5 lutego 1953 r. informował o kilkakrotnym nękaniu telefonami w godzinach wieczornych między 19.20 a 21.20. Relacjonował: „lżyli w okropny sposób księdza proboszcza, księży wikariuszy, zakonnice. Bluźnili przeciwko najświętszym tajemnicom naszej wiary. Ordynarnych wyzwisk i bluźnierstw nie sposób wypowiedzieć np. w stosunku do Matki Bożej. Chuligani uprawiali swój niecny proceder z jakiegoś publicznego lokalu i słychać było liczne śmiechy, nawoływania, np. «Mietak». Zmieniali się również przy słuchawce. Zaalarmowany Urząd Pocztowy z sąsiedniego numeru stwierdził, że zna numer telefonu chuliganów"61. W istocie urząd zidentyfikował numer i skierował sprawę do prokuratury ${ }^{62} .3$ marca 1953 r. ks. Wiącek po raz kolejny zwrócił się do Urzędu Pocztowego w Radomiu, informując o nękających telefonach (27 lutego o godz. 18.50 i 2 marca o godz. 21.10). Prosił o interwencję u wyższych władz w celu ukrócenia postępków "chuliganów"63. Prokuratura 10 marca odmówiła ścigania, gdyż "nie zostali ustaleni sprawcy"64.

59. AAN, UdSW, sygn. 11/27, Protokół z odprawy referentów wyznaniowych w Kielcach z 9 VIII 1952, s. 8.

6o. AAN, UdSW, sygn. 11/35, Protokół z odprawy kierowników RdSW woj. kieleckiego z 8 X 1952, s. 3.

61. ADS, Apk. J. Wiącka, Pismo ks. Wiącka do Urzędu Pocztowego w Radomiu z 5 II 1953.

62. ADS, Apk. J. Wiącka, Pismo Urzędu Pocztowego w Radomiu do ks. Wiącka z 5 II 1953.

63. ADS, Apk. J. Wiącka, Pismo ks. Wiącka do Urzędu Pocztowego w Radomiu z 3 III 1953.

64. ADS, Apk. J. Wiącka, Pismo ks. Wiącka bez adresata z 17 XI 1953. 
Nieustanne szykany i groźby były bardzo dokuczliwe, tym bardziej, że powtarzały się często po wyjściu proboszcza ze szpitala. Z tego powodu ks. Wiącek nie odebrał późnym wieczorem 9 marca 1953 r. telefonu z kurii. Miało to duże znaczenie, gdyż tą droga przekazywano polecenie uruchomienia dzwonów kościelnych w związku z pogrzebem Stalina. Polecenie to otrzymał od delegatów przybyłych z Prezydium MRN rankiem następnego dnia. Poinformował o tym sąsiednie parafie, które posiadały telefon. Dziekan tłumaczył sprawę w specjalnym liście do kurii wysłanym 10 marca $^{65}$.

Można się domyślać, że przesyłka, która nadeszła na adres ks. Wiącka pocztą, była kolejną prowokacją bezpieki (28 marca 1953 r.). Pakiet został opatrzony zaleceniem, by przekazać go za granicę. W środku miał się znajdować raport sekcji dywersyjno-sabotażowej. Dziekan wietrząc prowokację przekazał pakunek na Komendę Powiatową Milicji w Radomiu ${ }^{66}$.

Narzędziem umożliwiającym władzom komunistycznym prowadzenie skutecznej polityki wyznaniowej był dekret Rady Państwa z 9 lutego 1953 r. Wydanie go poprzedził pokazowy proces kurii krakowskiej (21-27 stycznia 1953 r.). Drakońskie wyroki, które tam zapadły, miały spowodować zastraszenie duchowieństwa. Atmosfera terroru był wszechobecna ${ }^{67}$. W istocie dekret dawał urzędnikom partyjno-administracyjnym całkowitą kontrolę nad obsadą wszystkich stanowisk kościelnych od wikariusza poczynając, na arcybiskupie kończąc. Ordynariusz przed każdą nominacją czy przeniesieniem księdza na inne stanowisko musiał uzyskać zgodę Prezydium WRN. Artykuł 6 umożliwiał także władzom usunięcie duchownych, którzy „uprawiali, popierali bądź osłaniali" działalność "sprzeczną z prawem i porządkiem publicznym"68. Takie sformułowanie stwarzało możliwość dowolnej interpretacji. Dodatkowo dekret przewidywał złożenie przez duchownych ślubowania na wierność PRL. Dawało to okazję do rozpoczęcia przez funkcjonariuszy UB gry operacyjnej zmierzającej do zastraszania duchowieństwa i werbowania tajnych współpracowników

65. ADS, Apk. J. Wiącka, Pismo ks. Wiącka do kurii z 10 III 1953.

66. Instytut Pamięci Narodowej w Warszawie [dalej: IPNBU], sygn. MBP 324, Kielce, Sprawozdanie WUBP w Kielcach za marzec 1953 r. z 14 IV 1953, s. 8.

67. F. Musiał, „... Jesteś księdzem więc musisz być wrogiem..." Przebieg tzw. procesu Kurii krakowskiej, w: Do prześladowania nie daliśmy powodu..., Materiały z sesji poświęconej procesowi Kurii krakowskiej, red. R. Terlecki, Kraków 2003, s. 113-147; F. Musiał, M. Lasota, Kościół zraniony. Proces księdza Lelity i sprawa Kurii krakowskiej, Kraków 2003.

68. Dz.U. PRL z 1953 Nr 10, poz. 32. 
(m.in. latem 1953 r. został pozyskany groźny informator „UL", później „Wąkop", - czyli ks. Wincenty Młodożeniec, proboszcz i dziekan w Iłży) ${ }^{69}$.

Koordynacja polityki wyznaniowej w województwie kieleckim zajmował się działający w sposób „ściśle tajny" Wojewódzki Zespół Organizacji Masowych przy KW PZPR w Kielcach (wchodzili do niego kierownicy: Referatu Organizacji Masowych przy KW - Władysław Skorek, Wojewódzkiego Referatu do Spraw Wyznań - Stefan Jarosz i Wydziału V Wojewódzkiego Urzędu Bezpieczeństwa Publicznego - kpt. Wiktor Muszyński ${ }^{70}$. Na zebraniach WZOM dyskutowano głównie nad polityką kadrową prowadzoną wobec Kościoła. Już 2 marca 1953 r. wytypowano do „zdjęcia z urzędu" kilku duchownych, w tym ks. Jana Wiącka ${ }^{71}$. Wkrótce żądania te zakomunikowano oficjalnie kurii sandomierskiej.

Sam zainteresowany o zarzutach, które stawiało mu Prezydium WRN w Kielcach, dowiedział się od ks. prał. Edwarda Górskiego, wikariusza generalnego z Sandomierza. Na jego polecenie 14 marca 1953 r. przesłał do kurii obszerne wyjaśnienia. Ks. Wiącek domyślał się, że pierwszy z zarzutów - jakoby wykazywał wrogi stosunek do PRL - został postawiony z powodu odmowy udziału w zjazdach organizowanych przez „ludzi niepoważnych" - chodziło o zebrania „księży patriotów" (szeroko omawiał te kwestie). Odmowa była podyktowana głębokim przekonaniem, że duchowni powinni dystansować się od spraw politycznych, które "budzą namiętności i wywołują sprzeciw, i ludzi dzielą". Ks. Wiącek odcinał się także od działalności konspiracyjnej jako „wybitnie szkodliwej". Jego zdaniem "ksiądz, który świadomie się jej oddaje, wyrządza olbrzymie szkody państwu i Kościołowi i sam wykazuje wielkie ubóstwo umysłowe". Władze miały też pretensje, że 9 marca 1953 r. w związku ze śmiercią Stalina nie chciał uruchomić dzwonów kościelnych. Proboszcz mariacki tłumaczył, że informację o poleceniu kurii przyniosło dwóch pracowników MRN w poniedziałek rano - 9 marca. Zastosował się do polecenia i zawiadomił parafie, które posiadały telefon. Natomiast oskarżenie jakoby przetrzymywał

69. Co ciekawe, ks. Młodożeniec został wytypowany do usunięcia z urzędu już 2 III 1953 (znajdował się na drugim miejscu listy po ks. Wiącku). Uniknął represji za cenę podjęcia współpracy z UB. B. Stanaszek, Diecezja..., dz. cyt., t. 1, s. 176-182, s. 291.

70. B. Stanaszek, Diecezja..., dz. cyt., t. 1, s. 85-150.

71. Archiwum Państwowe w Kielcach [dalej: APK], KW PZPR, sygn. 1910, Protokół posiedzenia WZOM z 2 III 1953, s. 3 . 
przez pół roku na plebanii bandę - było „z gruntu fałszywe". "Gdyby to była prawda, to władze inaczej by mnie potraktowały - oni sami w to nie wierzą" - uzasadniał. Wprost śmieszny był zarzut organizowania nielegalnych konferencji dla wikariuszy. Spotkania z nimi były konieczne do normalnego funkcjonowania parafii i zapewnienia właściwej pracy duszpasterskiej. Ks. Wiącek podkreślał, że na zebraniach nie poruszano tematów politycznych. Prosił też ordynariusza o wyznaczenie komisji w celu zbadania sprawy i podkreślał, że nie boi się "nawet najsurowszego osądu" ${ }^{2}$.

Tłumaczenia nie mogły jednak przekonać władz wyznaniowych, które z usunięciem ks. Wiącka wiązały ściśle określone cele - chodziło o przekazanie zarządu nad głównymi parafiami w Radomiu „księżom patriotom" - ludziom całkowicie uległym i dyspozycyjnym wobec komunistów. Działania te wpisywały się w politykę realizowaną przez władze komunistyczne w całej Polsce. Starały się one zmusić rządców diecezji do respektowania zapisów dekretu z 9 lutego 1953 r. ${ }^{73} .5$ maja 1953 r. Rada Ministrów wydała zarządzenie wykonawcze do wspomnianego dekretu, jednak, mimo narastającej presji, episkopat nie ustępował. Biskupi zebrani na konferencji w Krakowie 8 maja 1953 r. wystosowali do rządu memoriał kończący się słowami "Non possumus", w którym odrzucali tak daleko idące ingerencje władz państwowych w kościelną politykę personalną ${ }^{74}$. Jednak i komuniści nie zamierzali rezygnować. Wywierali coraz większy nacisk na rządców poszczególnych diecezji, aby podporządkowali się wymogom dekretu, realizowali też dobrze przemyślaną akcję ślubowania księży na wierność PRL.

Temat planowanych zmian personalnych wśród duchowieństwa podjęto ponownie na posiedzeniu WZOM w Kielcach 5 czerwca 1953 r.

72. ADS, Akta korespondencji z władzami cywilnymi (rozporządzeń i przeniesień) 1953-1975; List ks. J. Wiącka do bpa Lorka z 14 III 1953.

73. 11 III 1953 władze zażądały usunięcia ze stanowiska proboszcza katedry w Przemyślu ks. Jana Grochowskiego. M. Kapłon, Diecezja przemyska w latach 1944-1964, Rzeszów 2015, s. 2012. W archidiecezji krakowskiej w marcu 1953 r. władze żądały usunięcia księży: Jan Rutany, administratora parafii Libiąż Wielki, Józefa Jońca, dziekana i proboszcza w Oświęcimiu, Jana Marszałka, administratora parafii w Łodygowicach, Leonarda Prochownika, proboszcza z Wadowic oraz Bolesława Kominka, referenta kurii. S. Piskozub, Ksiadz Jan Rutana - administrator i proboszcz parafii Libiąż Wielki, Kraków 2016 (mps w Bibliotece UPJPII), s. 89.

74. B. Stanaszek, Diecezja..., dz. cyt., t. 1, s. 291-292; P. Reina, Kościół w PRL. Kościół katolicki a państwo w świetle dokumentów 1945-1989, t. 1, lata 1945-1959, Poznań 1994, s. 413-427. 
Wytypowano wówczas księży, których należało w pierwszej kolejności usunąć ze stanowisk. Wśród nich znalazło się czterech duchownych z diecezji kieleckiej i pięciu z sandomierskiej (m.in. Jan Wiącek) ${ }^{75}$. Żądania usunięcia niewygodnych księży przedstawił biskupowi sandomierskiemu Stefan Dybowski, przewodniczący Prezydium WRN w czasie spotkania w Kielcach 19 czerwca 1953 r. Proszony o podanie powodów takiej decyzji, przewodniczący nawiązał do poprzednich rozmów i stwierdził: „no cóż nie podoba im się Polska Ludowa i wszelkimi dostępnymi sobie środkami prowadzą z nią walkę. [...] ks. Wiącek w czasie okupacji, po wyzwoleniu powiązany był z wrogami klasy robotniczej, walczył przeciwko niej i walczy nadal [...], tacy księża nie mogą zajmować odpowiedzialnych placówek kościelnych". Bp Lorek próbował bronić księży. Wskazywał, że pozbawienie ks. Wiącka urzędu dziekana będzie wystarczającą karą dla niego. Podkreślał, że w Radomiu zrobił dużo dobrego, a jego ewentualne usunięcie "spowoduje rozgoryczenie ludności, a nawet może coś więcej, nie należy zadrażniać", jednak argumenty nie robiły na jego rozmówcy większego wrażenia. Zasugerował jedynie, by "dać im placówki liczące 2-2,5 tys.". W końcu biskup poprosił o sprecyzowania żądań na piśmie. Może w nadziei na uzyskanie ustępstw zadeklarował, że „zdejmie ks. Wiącka z dziekaństwa i składa gwarancję, że nic złego nie będzie z jego strony". Podczas rozmowy poruszono także inne sprawy. Biskup skarżył się, że na 11 wniosków w sprawie przenosin księży otrzymał aż 6 odmownych odpowiedzi, co "nasuwa trudności w administrowaniu diecezją" (w istocie taki był cel władz - chodziło o to, by decyzje o przenoszeniu księży zapadały nie w kurii, ale na biurku partyjnych urzędników). Przysłuchujący się rozmowie Stefan Jarosz, kierownik RdSW, podsumował w raporcie: „z rozmowy wynikało, że specjalnych oporów czynił nie będzie"76.

Rzeczywistość okazała się jednak inna. Bp Lorek nie kwapił się z wypełnieniem zaleceń. Żądał przedstawienia zarzutów na piśmie. 30 czerwca 1953 r. stosowny dokument podpisał Stefan Dybowski, przewodniczący Prezydium WRN w Kielcach. Żądanie było jednoznaczne: należy usunąć ks. Wiącka ze stanowiska dziekana i proboszcza w Radomiu ${ }^{77}$.

Przez kolejne miesiące miało trwać swoiste "przeciąganie liny". Ordynariusz sandomierski starał się wykorzystać wszelkie możliwości

75. APK, KW PZPR, sygn. 1910, Protokół posiedzenia WZOM z 5 VI 1953, s. 12.

76. AAN, UdSW, sygn. 37/227, Rozmowa z bpem Lorkiem z 19 VI 1953, s. 4-6.

77. ADS, Apk. J. Wiącka, Pismo Prezydium WRN w Kielcach do bpa J. Lorka z 30 VI 1953. 
odwołań i czekał na rozwój wypadków. Zwrócił się do Prezydium WRN w Kielcach o podanie na piśmie motywów, na podstawie których zażądano usunięcia ks. Wiącka (13 lipca 1953 r.). W odpowiedzi otrzymał lakoniczne pismo, w którym przytoczono treść art. 6 dekretu z 9 lutego 1953 r. („Uprawianie przez osobę piastującą duchowne stanowisko kościelne działalności sprzecznej z prawem i porządkiem publicznym bądź popieranie lub osłaniane takiej działalności powoduje usuniecie tej osoby z zajmowanego stanowiska przez zwierzchni organ kościelny samoistnie lub na żądanie organów państwowych") $)^{78}$.

Swoje wyjaśnienia do kurii ks. Wiącek nadesłał 12 sierpnia, kwestionując ogólne zarzuty i stwierdzając, że są zupełnie bezpodstawne. Oświadczył, że dobrowolnie nie opuści zajmowanego stanowiska, zażądał też przedstawienia i udowodnienia konkretnych oskarżeń. Pisał: „Nie wyobrażam sobie, aby w Polsce Ludowej obywatel został tak surowo ukarany pozbawieniem stanowiska, nie wiedząc co właściwie złego popełnił". Powołując się na par. 13 rozporządzenia wykonawczego Rady Ministrów do wspomnianego dekretu, prosił kurię o ustalenie konkretnych zarzutów stawianych przez władze wojewódzkie ${ }^{79}$.

14 sierpnia ks. Wiącek przygotował pismo do UdSW i przesłał je do kurii w celu złożenia w Warszawie. Wykazywał w nim, że jego działalność w Radomiu w żaden sposób nie zasługuje na wymierzenie kary. Wręcz przeciwnie, przywoływał konkretne fakty wskazujące na lojalność wobec władz państwowych. Przypominał, że jako proboszcz na Glinicach w 1945 r. przemawiał w czasie tradycyjnego "jajka wielkanocnego" zorganizowanego przez 3 Komisariat Milicji Obywatelskiej w Radomiu. Prowadzona przez niego budowa kościoła NSJ została bardzo pochlebnie oceniona w "Życiu Radomskim" z 22 sierpnia 1947 r., w artykule Radom wczoraj i dziś - Budowa monumentalnego kościoła na Glinicach. Wskazywał, że w czasie pobytu na Glinicach nie miał z władzami "najmniejszego zatargu czy nieporozumienia". Starał się współpracować w odbudowie i uporządkowaniu miasta, deklarując pomoc parafian w wybrukowaniu przylegającej do świątyni ul. Zalewskiego, "brudnej i bardzo zaniedbanej". Oferował nawet kamień polny zdatny do brukowania. Również jako proboszcz parafii mariackiej przy pomocy parafian

78. ADS, Apk. J. Wiącka, Pismo bpa Lorka do przewodniczącego Prezydium WRN w Kielcach z 13 VII 1953; Odpowiedź z 3 VIII 1953.

79. ADS, Apk. J. Wiącka, Pismo ks. Wiącka do kurii z 12 VIII 1953. 
w ciągu trzech lat sprawił, że kościół wcześniej niewykończony „przedstawia się jako jedna z najpiękniejszych świątyń w naszej diecezji". Podkreślał, że spłacił ogromne zadłużenie parafii wraz z podatkami do urzędu skarbowego. Traktował to jako wyraz lojalności obywatelskiej, choć wymiar podatków osobistych był bardzo wysoki i przekraczał możliwości płatnicze. Przypominał, że nadesłane na jego adres antypaństwowe ulotki natychmiast odesłał do UB. Wspominał też o szykanach ze strony władz (próba nieudanego dokwaterowania do plebanii 27 osób). Natomiast podany ustnie przez przewodniczącego Prezydium PWRN w Kielcach zarzut przynależności do Narodowych Sił Zbrojnych traktował jako „nikczemną kalumnię". Pisał też o motywach, którymi się kierował: „Nigdy nie dążyłem do zajęcia wyższego stanowiska, które jednak obejmowałem na wyraźny rozkaz. Rozgłosu ani sławy nie szukałem, nie szukałem też zysku osobistego ani wygody bytowania, świadomy, że tego poza grób zabrać nie mogę. Natomiast każdy grosz ciężko zapracowany wkładałem w dzieło, które prowadziłem". Wskazywał, że działalność sprzeczna z prawem stałaby w sprzeczności z powołaniem kapłańskim. Dlatego traktował decyzję Prezydium WRN w Kielcach jako w "najwyższym stopniu krzywdzącą". Prosił o podanie konkretnych powodów, które skłoniły Referat Wyznaniowy PWRN do żądania usunięcia ze stanowiska ${ }^{80}$.

19 sierpnia bp Lorek poinformował Prezydium WRN w Kielcach o stanowisku ks. Wiącka i jego odwołaniu do UdSW. Zaznaczył też, że prawo kanoniczne przy usuwaniu proboszcza wymaga poznania jego przewinień, przeprowadzenia postępowania w sądzie kościelnym i dopiero wówczas jest możliwa decyzja ordynariusza ${ }^{81}$. Bp Lorek prosił również o pośrednictwo sekretarza episkopatu bpa Zygmunta Choromańskiego. 12 sierpnia 1953 r. zapowiadał przyjazd ks. Wiącka do sekretariatu. Wobec braku konkretnych zarzutów wobec ks. Wiącka deklarował, że zamierza go bronić. Stwierdził, że ustnie podany zarzut należenia do NSZ jest bezpodstawny i krzywdzący ${ }^{82}$.

80. ADS, Apk. J. Wiącka, Pismo ks. Wiącka do UdSW z 14 VIII 1953; toż: AAN, UdSW, sygn. 56/68, s. 13; ASEP, sygn. 100/XVI, Pismo ks. J. Wiącka do Sekretariatu Episkopatu z 19 VIII 1953, s. 138-141.

81. ADS, Apk. J. Wiącka, Minuta listu bpa Lorka do PWRN w Kielcach z 19 VIII 1953.

82. ASEP, sygn. 100/XVI, s. 137, Pismo bpa Lorka do Sekretariatu Episkopatu z 12 VIII 1953. 
Wobec niespodziewanego opory Referat Organizacji Masowych KW PZPR w Kielcach w porozumieniu z I sekretarzem KW postanowił po raz ostatni wezwać bpa Lorka na rozmowę w sprawie usunięcia ks. Wiącka ${ }^{83}$. 18 sierpnia 1953 r. na posiedzeniu WZOM ustalono, by w rozmowie z biskupem 20 sierpnia zażądać kategorycznie zdjęcia wytypowanych księży (w tym Wiącka) ${ }^{84}$. Biskupa w istocie wezwano do Kielc w wyznaczonym terminie. Rozmowa trwała prawie trzy godziny (od 11.20 do 14.10) i była utrzymana w ostrym tonie. Uczestniczyli w niej zastępca przewodniczącego Prezydium PWRN - Sławomir Barwiński, sekretarz prezydium - Włodzimierz Kozak i kierownik RdSW - Stefan Jarosz. Biskup atakowany za niewykonanie personalnych przesunięć, których domagały się władze, bronił się, wskazując, że nie otrzymał pisemnego wniosku z podaniem motywów, a jedynie "suche pismo". Barwiński przypomniał, że motywy komunikowano ustnie. Biskup usiłował odpierać zarzuty wysuwane wobec ks. Wiącka, twierdząc, że są one nieprawdziwe. Mówił: „Nieprawda, że ks. Wiącek ukrywał bandytę, a że nie użył dzwonów w czasie pogrzebu Stalina, to miał wątpliwość czy Stalin, jako przywódca bezbożników mógł sobie tego życzyć - przecież dzwony biły w tamtejszej parafii". Zapowiedział, że wykorzysta wszystkie możliwości w jego obronie, a sam zainteresowany złożył odwołanie do UdSW. Sekretarz Kozak wygłosił podniosłe oświadczenie, że władza ludowa nie będzie tolerować wystąpień, jakich dopuścił się ks. Wiącek, bo „tego wymaga lud". W protokole zanotowano, że bp Lorek uśmiechał się ironicznie i powiedział: "lud wymaga tego, by usunąć ks. Wiącka? Lud chciał i chce go bronić i chcieli pisać petycję w tej sprawie, pojechać tu do was, tylko ks. Wiącek na to nie pozwolił"85. Replikował przewodniczący Barwiński: „Jesteśmy władzą

83. APK, KW PZPR, sygn. 3658, Pismo Referatu Organizacji Masowych KW PZPR w Kielcach do Wydziału Organizacji Masowych KC PZPR w Warszawie z 3 IX 1953 , S. $2-3$.

84. APK, KW PZPR, sygn. 1910, Protokół posiedzenia WZOM z 18 VIII 1953, s. 17.

85. AAN, UdSW, sygn. 64/86, Notatka z rozmowy z bpem Lorkiem z 20 VIII 1953, s. 4-6. Notatki z rozmowy wykonane przez stronę kościelną zachowały się w ASEP, sygn. 100/XVI, Notatki z rozmowy bpa Lorka z przewodniczącym PWRN w Kielcach z 20 VIII 1953, s. 142-143. Wyliczono tam zarzuty, które wysuwano przeciw ks. Wiąckowi (wrogie ustosunkowanie do „księży patriotów", atakowanie władzy ludowej i arogancja wobec niej, ukrywanie brata). Jeszcze jaśniej sprecyzował intencje władz sekretarz Prezydium WRN: „...Nie chodzi zresztą o ten czy inny zarzut. Ogólnie działalność ks. Wiącka jest antypaństwowa. Dlatego masy społeczne, czynniki robotnicze domagają się jego przeniesienia". Wiceprzewodniczący stwierdził też, że: „Radom jest ośrodkiem przemysłowym. Dyktatura proletariatu (jaką jest obecnie władza ludowa) wymaga ostrożności - ludzie nieodpowiedni 
dyktatury proletariatu, walka trwa i będziemy konsekwentnie walczyć z takimi wrogami, jakim jest ks. Wiącek i jemu podobni". O uzgodnieniu stanowisk nie mogło być mowy. Przysłuchujący się rozmowie Jarosz dorzucił na koniec, że „niewykonanie dekretu z 9 lutego spowoduje karę"86.

Bp Lorek nie zamierzał kapitulować. 24 sierpnia 1953 r. złożył odwołanie w UdSW, podkreślając, że po zbadaniu zarzutów nie może pozbawić ks. Wiącka stanowiska, gdyż działałby „wbrew sumieniu, wbrew zdrowej opinii parafian i wbrew przepisom prawa kościelnego"87. Kopię pisma przesłał do Sekretariatu Episkopatu, opatrując ją uwagą: „odnoszę wrażenie, że oni sami do tych zarzutów niewielką przywiązują wagę; to tylko pretekst. Istotnym jest, że osoba ks. kan. Wiącka zawadza im w Radomiu" ${ }^{\prime 8}$. O tym, że tak było w istocie, przekonał się bp Choromański, który podjął interwencję w obronie radomskiego proboszcza. Minister Antoni Bida, szef UdSW, oświadczył, że „ks. Wiącek musi ustąpić, bo jest nieprzychylny dzisiejszej rzeczywistości. Radom zaś ma wielkie znaczenie jako miasto biskupie - w takim środowisku musi pracować człowiek nam oddany"89.

26 sierpnia ks. Wiącek skierował kolejne odwołanie do UdSW, ustosunkowując się do nowych zarzutów „(1. Wrogie nastawienie do «księży patriotów» - zebrania - zaproszenia, 2. Arogancja i lekceważenie czynników władzy ludowej - sam proboszcz nieuchwytny i chowa się przed urzędnikami, 3. Nie uznanie nakazów Prezydium WRN odnośnie do odbudowy Warszawy, 4. Brat «bandyta» przechowywany na plebanii w Radomiu na Glinicach ul. Kościelna nr 3, 5. Jest kułakiem i z takiej rodziny pochodzi. Rodzina reakcyjna, nie potrafi zrozumieć przemian społecznych, tj. «dyktatury proletariatu» i do tych przemian się dostosować, 6. Gloryfikuje zasługi swojego

nie mogą zajmować takich stanowisk... Społeczeństwo, masy robotnicze, lud mają swoją władzę ludową, którą sobie wybrały. Ustosunkowanie się negatywne do władzy ludowej jest wyrazem tejże postawy do mas robotniczych". Jarosz twierdził, że żądanie usunięcia ks. Wiącka nie wymaga pisemnego uzasadnienia.

86. AAN, UdSW, sygn. 64/86, Notatka z rozmowy z bpem Lorkiem z 20 VIII 1953, s. 4-6.

87. AAN, UdSW, sygn. 56/68, Pismo bpa Lorka do UdSW z 24 VIII 1953, s. 1.

88. ASEP, sygn. 100/XVI, Pismo bpa Lorka do bpa Z. Choromańskiego z 25 VIII 1953, S. 143-144.

89. ASEP, sygn. 100/XVI, Pismo ks. Wiącka do Sekretariatu Episkopatu Polski z 28 VI 1953, s. 135-136, 137. Bida zagalopował się w tych wywodach - Radom nie był miastem biskupim. 
brata)". Oceniał, że zarzuty są „zupełnie mylące albo tendencyjne" i obszernie to uzasadniał ${ }^{90}$.

Wszelkie wyjaśnienia nie miały jednak żadnego znaczenia dla władz. Ks. Wiącka traktowano jako „wroga". Ostro występował przeciw niemu informator UB ps. „Ul" (ks. Wincenty Młodożeniec, który za podjęcie współpracy ostał się na stanowisku proboszcza i dziekana w Iłży). Podkreślał on, że ks. Wiącek jest "bezkompromisowy, trochę awanturnik, to człowiek najbardziej zaufany biskupa. Można powiedzieć, że to prawa ręka biskupa. Jest w bliskich stosunkach z prymasem Wyszyńskim"19.

Ten ostatni argument zaakcentowano w oficjalnym piśmie kieleckiego RdSW przesłanym do Warszawy. Czytamy w nim: „jest kolegą uniwersyteckim prymasa Wyszyńskiego, a ten z kolei jest kolegą bpa Lorka i dlatego ks. Wiącek ma poparcie i zaufanie u władz kościelnych. Na jego plebanii są dwa pokoje zarezerwowane, gdzie zatrzymuje się bp Lorek, odwiedza go również i prymas Wyszyński, gdy przejeżdża przez Radom. Dla zamaskowania tych pokoi ks. Wiącek wywiesił na drzwiach tabliczkę z napisem «Sąd Biskupi - Ekspozytura w Radomiu»". Oceniano także, że "ks. Wiącek jest jednym z najwierniejszych dziekanów bpa Lorka i kontynuatorem jego polityki i zarządzeń". Końcowy wniosek zawierał się w stwierdzeniu: „Zdecydowany wróg obecnego ustroju i na stanowisku proboszcza i dziekana w Radomiu pozostać nie może". Ponadto w opinii odnotowano: „Występuje przeciw księżom, którzy biorą udział w zjazdach, należą do KK przy ZBoWiD, wskazując, że zjazdy przeciw hierarchii, a księża, który biorą udział, są nie w porządku wobec zarządzeń bpa Lorka [to zdanie podkreślone- BS]. Na konferencji dekanalnej 5 września 1950 r. wskazywał na nieprzestrzeganie zawartego porozumienia przez władze szkolne. Przypomniał zarządzenie biskupa, że nie wolno angażować się do pracy w «Caritasie», a akcje charytatywne prowadzić należy przy kościołach. Oświadczenie episkopatu w sprawie «Caritas» odczytał i polecił odczytać innym księżom. Jego bracia należeli do AK - Józef w 1944 r. został awansowany na kapitana. Po wyzwoleniu Józef wstąpił do UB i pracował w Wojewódzkim Urzędzie z siedzibą w Sandomierzu, skąd zdezerterował. Zorganizował wtedy nielegalną organizację «Jędrusie». W 1 poł. 1945 r. został ranny w akcji i schwytany przez

90. AAN, UdSW, sygn. 56/68, Pismo ks. Wiącka do UdSW z 26 VIII 1953, s. 2-6; Odpis: ADS, Apk. J. Wiącka.

91. IPNBU, sygn. IPN 00611/1844, t. 2, Teczka pracy „Ul”, cz. 2, Doniesienie nr 3 z 14 VIII 1953, k. 1.

Ks. Bogdan Stanaszek, Represje władz komunistycznych... 
UB. Postawiono go przed sadem, ale zwolniono z braku dowodów. Brat Stanisław odsiaduje karę 15 lat więzienia. Siostra pracowała w konsulacie polskim w Paryżu. Ks. Wiącek odmówił bicia w dzwony w czasie pogrzebu tow. Stalina. Dopiero po mocnej interwencji wyraził zgodę"92.

Wobec takich ocen nie mogło więc nikogo zdziwić, że 9 września 1953 r. UdSW przesłał do sandomierskiej kurii żądanie usunięcia ks. Wiącka. Podkreślono, że decyzja jest ostateczna ${ }^{93}$. Dodatkową szykaną zastosowaną wobec parafii mariackiej było pozbawienia prawa nauczania większości tamtejszych wikariuszy. Tym samym w większości szkół nie było religii albo odbywała się w niewielkim wymiarze ${ }^{94}$.

W celu przezwyciężenia oporu episkopatu i większego zastraszenia biskupów władze państwowe zorganizowały proces pokazowy bpa Czesława Kaczmarka, ordynariusza diecezji kieleckiej (14-22 września 1953 r.), którego skazano na 12 lat więzienia, oraz aresztowały prymasa Stefana Wyszyńskiego (25/25 września 1953 r.). Tuż przed wyjazdem do Warszawy na zjazd episkopatu bp Lorek, ordynariusz diecezji sandomierskiej, sporządził uzupełnienie do testamentu. Wspomniał, że robi to licząc się z możliwością aresztowania $^{95}$.

Atmosfera polityczna stawała się coraz bardziej napięta. Funkcjonariusze UB, jak nigdy wcześniej, zabiegali o odczytanie komunikatu episkopatu z 28 września 1953 r., w którym potępiono "fakty ujawnione w procesie bpa Czesława Kaczmarka"96. Z wielką uwagą śledzono też reakcje duchowieństwa na zaistniałą sytuację. W sprawozdaniu WUBP w Kielcach za wrzesień 1953 r. zanotowano, że „fakt izolowania prymasa Wyszyńskiego pogłębił jeszcze bardziej niepewność księży co do dalszych posunięć władz państwowych w stosunku do kleru". „Wroga część kleru" wskazywała, że rząd prowadzi walkę z religią ${ }^{97}$. Papierkiem lakmusowym do zbadania

92. AAN, UdSW, sygn. 56/68, Pismo WdSW PWRN w Kielcach do UdSW z 25 VIII 1953, S. 7-8, 55. Ks. Skurski twierdził, że według powszechnej opinii bp Lorek mianował ks. Wiącka proboszczem w Radomiu na skutek bezpośredniej interwencji prymasa Wyszyńskiego.

93. AAN, UdSW, sygn. 56/68, Pismo UdSW do bpa Lorka z 9 IX 1953 s. 150; toż: ADS, Apk. J. Wiącka.

94. $\quad$ ADS, Apk. J. Wiącka, Pismo ks. Wiącka do kurii z 6 IX 1953.

95. B. Stanaszek, Usunać biskupa! Władze PRL wobec ordynariusza diecezji sandomierskiej Jana Kantego Lorka, Sandomierz 2004, s. 81-82.

96. P. Reina, Kościół w PRL..., t. 1, s. 446-447.

97. IPNBU, sygn. MBP 324, Kielce, Sprawozdanie WUBP w Kielcach za wrzesień 1953 S. 2. 
tych nastrojów miała być reakcja księży na wspomnianą kontrowersyjną odezwę episkopatu. 30 września 1953 r. sekretarz KC PZPR Edward Ochab zalecił I sekretarzom komitetów wojewódzkich dopilnowanie, by księża we wszystkich kościołach odczytali komunikat biskupów. Akcja miała być przeprowadzona dyskretnie, z wykluczeniem bezpośredniej ingerencji partii i UB. Należało obserwować teren, zwłaszcza tam, gdzie zachowanie kleru budziło zastrzeżenia. Miała temu towarzyszyć agitacja w związku z nasilającą się wrogą kampanią radiową. W województwie kieleckim, do którego Radom należał, UB przeprowadził akcję sprawdzającą, czy list został odczytany we wszystkich kościołach ${ }^{98}$. Ks. Wiącek odczytał ten komunikat w swoim kościele ${ }^{99}$.

Nadal trwały szykany fiskalne. 21 października 1953 r. ks. Wiącek skierował kolejne pismo do ministra finansów, protestując przeciw szykanom podatkowym. Podkreślał, że co miesiąc płaci przeszło $1000 \mathrm{zł}$, prowadzi księgę nr 11, do której wpisuje wpłacane przez wiernych ofiary. Podczas kontroli urzędnik nie wniósł żadnych zastrzeżeń do sposobu prowadzenia dokumentacji. Jednak 17 lipca ks. Wiącek otrzymał nakaz płatniczy za 1951 r. (9273 zł) i domiar płatniczy za 1952 r. (6881 zł 58 gr). 17 sierpnia nadszedł drugi domiar za 1952 r. (suma ogólna 11106 zł). 19 października otrzymał trzeci nakaz płatniczy za rok 1953 - suma 23853 zł. Nadeszło również upomnienie z informacją, że do powyższych sum zostanie doliczony podatek za zwłokę. Ks. Wiącek argumentował, że Wydział Finansowy przyjmuje, iż jego dochód miesięczny wynosi 3681 zł. Pisał: „Jeśli na chwilę przyjmiemy tę sumę i chcielibyśmy zapłacić powyższe nakazy płatnicze za trzy lata, to suma, jaką wypadnie spłacić miesięcznie, większą będzie niż cały rzekomy dochód brutto, jaki przyjmuje Wydział Finansowy". Zapłacenie takich kwot było niemożliwe. Proboszcz prosił więc o uchylenie decyzji Wydziału Finansowego i uwzględnienie przy wymiarze podatkowym księgi podatkowej ${ }^{100}$.

98. Szerzej: B. Stanaszek, Ślubowanie księży na wierność $P R L$ w diecezji sandomierskiej w 1953 r., w: Historia świadectwem czasów. Księdzu Profesorowi Markowi Tomaszowi Zahajkiewiczowi, Lublin 2006, s. 445.

99. ADS, Apk. J. Wiącka, Pismo ks. Wiącka do Ministra Finansów z 21 X 1953.

100. ADS, Apk. J. Wiącka, Pismo ks. Wiącka do Ministra Finansów z 21 X 1953. Ks. Wiącek wskazywał, że proboszcz partycypuje przeciętnie w 60 proc. w dochodach parafialnych po potrąceniu opłat na kościół i służbę kościelną). Wikariusz uzyskiwał 40 proc. Tymczasem podatek proboszcza był czterokrotnie wyższy niż wikariusza. 
W październiku 1953 r. w wielu miastach urządzano zebrania i wiece, podczas których atakowano Watykan, prymasa i hierarchię kościelną. Zebranie takie zaplanowano też w Radomiu. Przygotowując je, 12 października 1953 r. władze wezwały do Prezydium MRN pięciu proboszczów parafii radomskich i dwóch przedstawicieli zakonów. Zapowiedziano wówczas, że w piątek 15 października odbędzie się zebranie w Domu Kultury, na którym zostanie wygłoszony referat Normalizacja stosunków między państwem i Kościołem. Księżom wręczono zaproszenia do prezydium, jednak spotkało się to z oporem z ich strony. Ks. Kosiński oświadczył, że przed wojną "chcieli go zapisać do sanacji - odmówił i potem socjalista Grzecznarowski chwalił go za to". Natomiast ks. Wiącek oświadczył, że nie przyjdzie na zebranie, gdyż „polityka dzieli ludzi nawet w jednej rodzinie..., a ksiądz winien być dla wszystkich". W odpowiedzi udzielono mu ostrzeżenia, że "to się źle skończy". Na zebranie w 15 października 1953 r. nie poszedł żaden z księży radomskich. Odczytany referat zawierał inwektywy pod adresem papieża, prymasa, hierarchii. Ks. Stanisław Skurski, proboszcz z Wszechświętych, jeden z czołowych przedstawicieli ruchu "księży patriotów", zabierając głos w dyskusji oświadczył: „Prawda była w referacie, ksiądz prymas za dolary amerykańskie sprzedawał Polskę". Atakował także biskupów Lorka i Kaczmarka. Według informacji pozyskanych przez ks. Wiącka młodzież z kursów wieczorowych "spędzona na zebranie" wyrażała dezaprobatę głośnym tupaniem nogami, zaś co odważniejsi wychodzili z sali. Na zakończenie odbyła się libacja w lokalu Caritasu przy ul. Słowackiego, na która " przygotowano 11 litrów gorzały". Ks. Skurski ubolewał nad duchowieństwem, że jest reakcyjnie nastawione; "pili zdrowie ks. Skurskiego proboszcza parafii mariackiej"101.

10 listopada 1953 r. w czasie rozmowy z referentem wyznaniowym ks. Wiacek był indagowany, z czyjej inicjatywy zostały odprawione w kościele Mariackim w Radomiu msze święte w intencji bpa Kaczmarka i prymasa Wyszyńskiego. Zaprzeczył temu zdecydowanie, oświadczając, że to byłaby prowokacja ${ }^{102} .17$ listopada ks. Wiącek przygotował obszerne pismo, w którym odpierał zarzuty stawiane przez władze. Wskazywał w nim, że

101. ASEP, sygn. 100/XVI, s. 166-167, Pismo ks. Wiącka do kurii z 20 XII 1956; toż w: ADS, Apk. J. Wiącka.

102. AAN, sygn. 56/68, Notatka z rozmowy telefonicznej S. Jarosza z ks. Wiąckiem Z 10 XI 1953, s. 98. 
stoi za nimi Stefan Jarosz, kierownik RdSW PWRN w Kielcach, który darzy go osobistą niechęcią ${ }^{103}$.

Los proboszcza był właściwie przesądzony. Mimo to bp Lorek nadal usiłował go bronić. 8 października wikariusz generalny ks. prał. Edward Górski w czasie rozmowy z kierownikiem RdSW w Kielcach oświadczył, że ks. Wiącka: „zgodnie z decyzją min. Bidy zdjęliśmy ze stanowiska dziekana, a proboszczem jest nadal, bo taki «był tenor pisma ministra»". Jarosz od razu ripostował, że żądanie dotyczyło także urzędu proboszcza ${ }^{104}$. Na posiedzeniu WZOM z 12 listopada 1953 r. omawiano pismo bpa Lorka, w którym ordynariusz sandomierski twierdził, że wypełnił żądania władz, odwołując ks. Wiącka z urzędu dziekana, pozostawiając nadal proboszczem. Zdecydowano, by wezwać biskupa do Prezydium WRN i zażądać usunięcia ks. Wiącka z probostwa w ciągu $14 \mathrm{dni}^{105}$. Zakomunikowano to ks. prał. Górskiemu podczas rozmowy w Kielcach 20 listopada. Wikariusz generalny poprosił wówczas o przedłużenie terminu do 10 grudnia ${ }^{106} .25$ listopada $1953 \mathrm{r}$. w oficjalnym piśmie prezydium do kurii ponownie zażądano wykonania tych zaleceń w wyznaczonym terminie ${ }^{107}$. Na nic się zdało odwołanie, które ks. Wiącek wysłał do UdSW (25 listopada 1953 r.) ${ }^{108}$.

Wobec silnej presji 1 grudnia bp Lorek oficjalnie zawiadomił Prezydium WRN w Kiecach o usunięciu ks. Jana Wiącka ze stanowiska proboszcza w Radomiu i powierzeniu od 10 grudnia tymczasowej administracji parafii najstarszemu wikariuszowi ks. Wacławowi Kazimierzowi Dunikowskiemu ${ }^{109}$.

103. ADS, Apk. J. Wiącka, Pismo ks. Wiącka bez adresata z 17 XI 1953.

104. AAN, UdSW, sygn. 64/86, Notatka z rozmowy z wikariuszem gen. ks. prał. E. Górskim 8 X 1953, s. 7-10; por. AAN, UdSW, sygn. 56/68, Pismo WdSW PWRN w Kielcach do UdSW z 27 X 1953 r., s. 21. Jarosz informował UdSW, że bp Lorek pozbawił ks. Wiącka stanowiska dziekana. Jego następcą został ks. Nowakowski, mianowany bez uzgodnienia z RdSW.

105. APK, KW PZPR, sygn. 1910, Protokół posiedzenia WZOM z 12 XI 1953, s. 28.

106. ADS, Akta korespondencji z władzami cywilnymi 1953-1975, Notatki z rozmowy ks. Górskiego z przewodniczącym PWRN w Kielcach z 20 XI 1953.

107. AAN, UdSW, sygn. 56/68, Pismo PWRN w Kielcach do kurii w Sandomierzu z 20 XI 1953, s. 151.

108. AAN, UdSW, sygn. 56/68, Pismo ks. Wiącka do dyrektora UdSW z 25 XI 1953, s. 34-35. Ks. Wiącek pisał, że w wyborach głosowałjak wszyscy księża i „poparł tezy Frontu Narodowego". Podkreślił, że nie stwarzał przeszkód, by jeden z księży wszedł do Komisji Księży przy Froncie Narodowym, a na ostatnim zebraniu zorganizowanym w Kielcach było pięciu księży z dekanatu radomskiego. Ks. Wiącek nie uczestniczył w nim, gdyż, jak pisał, nie otrzymał zaproszenia. Zarzuty władz uważał za niesłuszne.

109. ADS, Apk. J. Wiącka, Minuta pismo bpa Lorka do PWRN w Kielcach z 1 XII 1953. 
Ks. Wiącek otrzymał urlop zdrowotny (od 10 grudnia 1953 r.) i wyjechał na leczenie do Krynicy, zaś władze oceniały, że jego choroba "jest upozorowana". Przed opuszczeniem Radomia napisał list pożegnalny do wiernych, w którym podkreślił, że musi odejść na żądanie władz administracyjnych. Po złożeniu sprawozdania z wykonanych prac wspomniał też o planach założenia centralnego ogrzewania w kościele. Wierni samorzutnie zorganizowali zbieranie podpisów pod petycjami o pozostawienie proboszcza w Radomiu. Dopiero interwencja WUBP położyła kres tej akcji. Oceniając przebieg "sprawy ks. Wiącka", kierownik Referatu Organizacji Masowych KW PZPR w Kielcach Władysław Skorek stwierdzał, że napotkano „poważne trudności ze strony biskupa Lorka, który bardzo uporczywie stał w obronie ks. Wiącka". Zauważał też, że sandomierski hierarcha parafie o większym znaczeniu powierza tymczasowym administratorom, chcąc w ten sposób uniknąć uzgodnień z władzami (parafia Radom-Glinice i parafia mariacka). Skorek oceniał, że to "od dawna wypróbowana przez niego [biskupa- BS] metoda, aby wszystkie sprawy odwlekać dokąd się tylko da"110.

Na początku grudnia ks. Wiącek skierował jeszcze list do kurii, w którym wskazywał, że Prezydium WRN pomija milczeniem instrukcję nr 27 z 9 października 1953 r., w której pisano o ustaleniu i sprawdzeniu okoliczności, uzasadniających potrzebę zastosowania art. 6 dekretu z 9 lutego 1953 r. Była w niej mowa o upomnieniu duchownego przez biskupa. Dopiero w przypadku powtórzenia się wykroczeń było możliwe stosowanie art. 6. Ks. Wiącek wskazywał, ze procedura ta w jego przypadku została pominięta. Podkreślał, że na swoje odwołanie do szefa UdSW otrzymał decyzję usunięcia ze stanowiska dziekana. 25 listopada ks. Wiącek rozmawiał z ministrem Bidą w Warszawie i usłyszał, że "po przestudiowaniu akt sprawy nie widzi jakiejś wrogiej działalności przeciwko Państwu Ludowemu", ale „widzi, jak się wyraził brak serca i entuzjazmu dla Polski Ludowej". Nie było wówczas mowy o wiążącym terminie usunięcia ze stanowiska proboszcza. Natomiast - argumentował ks. Wiącek - „brak serca i entuzjazmu nie stanowi przestępstwa w sensie prawnym do usunięcia ze stanowiska kościelnego". Ks. Wiącek w zaistniałej sytuacji poprosił o udzielenie "bezterminowego urlopu"11.

110. APK, KW PZPR, sygn. 3661, Sprawozdanie Referatu Organizacji Masowych za XII 1953, s. 183, 205-206, 210.

111. ADS, Apk. J. Wiącka, Pismo ks. Wiącka do kurii z 6 XII 1953. 
Władze komunistyczne nie dopuściły ks. Wiącka do piątej tury ślubowania księży na wierność PRL, która odbyła się 12 grudnia 1953 r. ${ }^{12}$ Nawet w tej beznadziejnej sytuacji bronił go ordynariusz sandomierski. 24 grudnia 1954 r. złożył zażalenie do Rady Państwa; skierował też kilka pism do sekretarza episkopatu ${ }^{113}$. Ostatecznie na odwołanie odpowiedział dyrektor UdSW Antoni Bida. Lakonicznie stwierdził, że decyzja dotycząca ks. Wiącka została podjęta "dla dobra współpracy miedzy Kościołem a Państwem w Polsce Ludowej"114.

24 grudnia 1953 r. zmarł ks. Wacław Kosiński, proboszcz parafii pw. św. Jana w Radomiu ${ }^{115}$. Opróżnienie dwóch największych parafii w diecezji dało komunistom okazję do wywarcia większego nacisku na sandomierską kurię w celu obsadzenia ich przez „księży patriotów". Bpa Lorka wezwano na kolejną rozmowę do Prezydium WRN w Kielcach (21 stycznia 1954 r.). Nawet wtedy bronił ks. Wiącka. Jarosz jednak rozwiał nadzieje na możliwość jego powrotu do Radomia. Bezceremonialnie stwierdził, że w największym mieście województwa potrzebny jest bezzwłocznie ksiądz, który „mógłby odpowiednio ułożyć stosunki między księżmi a władzami miejscowymi oraz rozładować tę atmosferę nieufności i wrogości, jaką pozostawił poprzez swój wpływ ks. Wiącek na pozostałych księżach". Wiceprzewodniczący Barwiński dodał: „nie zgodzimy się na objęcie tego stanowiska przez księdza, który nie chce zrozumieć interesów i potrzeb ludu pracującego w Radomiu, nie potrafi znaleźć wspólnego języka z władzami". Urzędnicy usiłowali przeforsować swoje kandydatury na opróżnione stanowiska. Rozmowa zakończyła się polemiką wokół interpretacji dekretu o obsadzaniu stanowisk kościelnych z 9 lutego 1953 r. Jarosz podkreślił, że uprawnia on władze do „czynnego udziału w obsadzaniu stanowisk kościelnych, Radom jest bardzo ważną placówką i ksiądz [biskup - BS] tam wroga Polski Ludowej nie wsadzi, bo my na to nie pozwolimy". Natomiast bp Lorek przypomniał, że dekret z 9 II 1953 r. daje władzom wyznaniowym możliwość zatwierdzania lub odrzucenia zgłoszonych kandydatów, a nie wysuwania ich. Notatka z rozmowy przeprowadzonej z biskupem trafiła na biurko ministra Bidy w UdSW i do KC PZPR ${ }^{116}$.

112. B. Stanaszek, Diecezja..., dz. cyt., t. 1, s. 305.

113. ASEP, sygn. 100/XVI, s. 153, Pismo bpa Lorka do Rady Państwa z 24 XII 1953; toż: ADS, Apk. J. Wiącka.

114. ADS, Apk. J. Wiącka, Pismo min. Bidy do bpa Lorka z 4 I 1954.

115. B. Stanaszek, Księża diecezji..., dz. cyt., t. 1, s. 68.

116. AAN, UdSW, sygn. 44/246, Notatka z rozmowy z bpem Lorkiem z 21 I 1954, s. 2-4.

Ks. Bogdan Stanaszek, Represje władz komunistycznych... 
W kilka dni po spotkaniu (25 stycznia 1954 r.) bp Lorek oficjalnie zgłosił propozycje personalne obsady parafii radomskich, jednak nie zostały one zaakceptowane. RdSW zgodził się natomiast na przeniesienie ks. Wiącka na probostwo do Koprzywnicy ${ }^{117}$. Akceptacja wynikała zapewne z obawy, aby bp Lorek nie starał się o jego powrót do Radomia. 8 lutego z Wydziału do Spraw Wyznań na adres kurii wysłano pismo dla ks. Wiącka z wezwaniem na rozmowę urzędową do Kielc 22 lutego na godz. 11 (Plac Zamkowy nr 1, pokój 115). Pismo przekazano do Sandomierza ze względu na brak aktualnego adresu ks. Wiącka. Stad wyekspediowano je do Krynicy, gdzie przebywał on na urlopie kuracyjnym (Willa Pod Pogonią, ul. Kościelna) ${ }^{118}$.

Podczas spotkania w Kielcach kierownik RdSW Stefan Jarosz oświadczył, że po wyjeździe ks. Wiącka z Radomia okazało się, że wiele zarzutów było niesłusznych, "parafia mariacka jest jeszcze nie obsadzona i może być do objęcia, jest to sprawa do omówienia" - kusił. Ks. Wiącek nie był jednak podatny na tego typu oferty. Stwierdził, że obsada parafii należy do kompetencji biskupa i uchylił się od kontynuowania tego tematu. W relacji przesłanej do Sekretariatu Episkopatu pisał: „wnioskuję z tego, że nic się za darmo od p. Jarosza nie otrzymuje i łaska jego zmusza do lojalności i grzeczności". Rozmowa zakończyła się poleceniem, by następnego dnia ks. Wiącek przybył na ślubowanie ${ }^{119}$. Nominacja na probostwo w Koprzywnicy nosiła datę 23 lutego. Oficjalnie objął je 3 marca 1954 r. $^{120}$

Spór władz państwowych z biskupem sandomierskim dotyczący obsady parafii radomskich ciągnął się do połowy 1954 r. ${ }^{121}$ Ostatecznie proboszczem kościoła Mariackiego po ks. Wiącku został ks. Wacław Pośpieszyński, proboszcz parafii św. Michała w Ostrowcu Świętokrzyskim i dziekan

117. AAN, UdSW, sygn. 44/246, Pismo RdSW PWRN w Kielcach do UdSW z 8 II 1954, s. 5-7; ADS, Apk. J. Wiącka, Pismo PWRN do bpa Lorka, wpł. 10 II 1954.

118. ADS, Apk. J. Wiącka, Pismo PWRN do ks. Wiącka z 8 II 1953; Pismo kurii do ks. Wiącka z 10 II 1953.

119. ASEP, sygn. 100/XVI, s. 169-170, Pismo ks. Wiącka kurii z 20 XII 1956. W materiałach władz wyznaniowych podano inny termin złożenia ślubowania przez ks. Wiącka: AAN, UdSW, sygn. 56/68, s. 68: „Do ślubowania nie został dopuszczony, gdyż jego wroga postawa nie zezwalała na to, aby fałszywie ślubowal" [1953 r.]. AAN, UdSW, sygn. 56/68, s. 97, formularz ślubowania podpisany przez ks. Wiącka 23 IX 1954 r.

120. ADS, Apk. J. Wiącka, Nominacja z 23 II 1954; AAN, UdSW, sygn. 56/68, Pismo WdSW PWRN w Kielcach do UdSW z 3 II 1954, s. 58, 60.

121. Szerzej: B. Stanaszek, Diecezja...., dz. cyt., t. 1, s. 309-316. 
tamtejszego dekanatu (informator UB o ps. "Antoni"122). Lansowany wcześniej przez władze na to stanowisko ks. Stanisław Skurski, działacz Caritasu, został proboszczem parafii św. Jana ${ }^{123}$. Ks. Wiącek do Radomia już nie wrócił, mimo starań podejmowanych w $1957 \mathrm{r} .{ }^{124}$ Jako proboszcz koprzywnicki nadal był uznawany za "wroga PRL" i inwigilowany przez SB ${ }^{125}$.

122. Instytut Pamięci Narodowej Oddział w Krakowie Delegatura w Kielcach [dalej: IPNK], sygn. IPN Ki 015/824, t. 5, k. 82-83, J. Walaszczyk, Charakterystyka inf. "Antoni" nr rej. 191/55 z 7 XII 1955 (pozyskany do współpracy w 1951 r.).

123. B. Stanaszek, Diecezja...., dz. cyt., t. 1, s. 315.

124. B. Stanaszek, Konflikty..., dz. cyt., s. 510-512.

125. IPNK, sygn. IPN Ki 015-670, t. 5, Charakterystyka kontrwywiadowcza dotycząca zagadnienia kleru z 12 VI 1959 s. 14; IPNK, sygn. IPN Ki 015-679, t. 1, Informacja dotycząca postawy społeczno-politycznej księży z terenu powiatu sandomierskiego z 26 VII 1961, s. 33 . 


\section{Bibliografia}

Źródła archiwalne:

Archiwum Akt Nowych w Warszawie.

Zespół: Ministerstwo Administracji Publicznej, sygn. 959.

Zespół: Urząd do spraw Wyznań, sygn. 7/5, sygn. 11/27, sygn. 11/35,

sygn. $37 / 227$, sygn. $44 / 246$, sygn. $56 / 68$, sygn. $64 / 86$.

Archiwum Diecezjalne w Sandomierzu (brak sygnatur).

Akta korespondencji z władzami cywilnymi (rozporządzeń

i przeniesień) 1953-1975.

Akta kościoła parafialnego św. Jana w Radomiu 1845-1929.

Akta kościoła parafialnego Opieki Najświętszej Maryi Panny

w Radomiu (1949-1989).

Akta personalne księdza J. Wiącka.

Archiwum Katedry pw. Opieki NMP w Radomiu (brak sygnatur), Kronika parafii katedralnej Opieki NMP w Radomiu 1938-1988.

Archiwum Państwowe w Kielcach, Zespół KW PZPR w Kielcach, sygn. 1910, sygn. 3658, sygn. 3661.

Archiwum Parafii NSJ w Radomiu (bez sygnatur), Kronika parafialna $1921-1987$.

Archiwum Sekretariatu Episkopatu Polski w Warszawie, sygn. 100/XVI. Instytut Pamięci Narodowej Oddział w Krakowie, Delegatura w Kielcach, sygn. IPN Ki 015-670, t. 5, sygn. IPN Ki 015/824, t. 5.

Instytut Pamięci Narodowej w Warszawie, sygn. MBP 324; sygn. IPN 00611/1844.

Źródła drukowane:

Dz.U. PRl z 1953 Nr 10, poz. 32.

P. Reina, Kościół w PRL. Kościół katolicki a państwo w świetle dokumentów 1945-1989, t. 1, lata 1945-1959, Poznań 1994. 
Wspomnienie o księdzu kanoniku doktorze Janie Wiącku Proboszczu

Parafii pw. św. Floriana w Koprzywnicy w latach 1954-1973,

Koprzywnica 2004.

Źródła internetowe:

http://www.nsj.radom.pl/historia.html, (13.07.2016).

\section{Opracowania:}

M. Kapłon, Diecezja przemyska w latach 1944-1964, Rzeszów 2015.

Sz. Kowalik, Fabrica ecclesiae. Żywot i sprawy radomskiego proboszcza ks. Piotra Górskiego (1843-1930), Radom 2016.

S. Makarewicz, Mistrzowie wiary. Błogosławieni męczennicy radomscy z grona 108 męczenników za wiarę z okresu drugiej wojny światowej, Sandomierz 2001.

F. Musiał, „... Jesteś księdzem więc musisz być wrogiem..." Przebieg tzw. procesu Kurii krakowskiej, [w:] Do prześladowania nie daliśmy powodu..., Materiały z sesji poświęconej procesowi Kurii krakowskiej, red. R. Terlecki, Kraków 2003, s. 113-147.

F. Musiał M. Lasota, Kościół zraniony. Proces księdza Lelity i sprawa Kurii krakowskiej, Kraków 2003.

S. Piskozub, Ksiadz Jan Rutana - administrator i proboszcz parafii Libią̇ Wielki, Kraków 2016, mps w Bibliotece UPJPII.

A. L. Sowa, Od Drugiej do Trzeciej Rzeczypospolitej (1945-20o1), Kraków 2001

B. Stanaszek, Diecezja sandomierska w powojennej rzeczywistości politycznej 1945-1967, t. 1, Problematyka personalno-organizacyjna, Sandomierz 2006.

B. Stanaszek, Diecezja sandomierska w powojennej rzeczywistości politycznej 1945-1967, t. 2, Sandomierz 2006.

B. Stanaszek, "Kolega" prymasa Wyszyńskiego. Ks. Jan Wiącek (19oo-1973), "Nasz Dziennik" 2008, nr 34 (2051), s. 23-25.

B. Stanaszek, Konflikty władz wyznaniowych z biskupem sandomierskim o obsade parafii radomskich w latach 1953-1956, "Studia Diecezji Radomskiej" 6 (2004), s. 483-512.

B. Stanaszek, Kosiński Wacław, [w:] Leksykon duchowieństwa represjonowanego w PRL w latach 1945-1989, t. 1. Warszawa 2002, s. $123-124$. 
B. Stanaszek, Księża diecezji sandomierskiej więzieni przez władze komunistyczne po II wojnie światowej, Rzeszów 2008.

B. Stanaszek, Ślubowanie księży na wierność PRL w diecezji sandomierskiej w 1953 r., [w:] Historia świadectwem czasów. Księdzu Profesorowi Markowi Tomaszowi Zahajkiewiczowi, Lublin 2006, s. 431-446.

B. Stanaszek, Usunać biskupa! Władze PRL wobec ordynariusza diecezji sandomierskiej Jana Kantego Lorka, Sandomierz 2004.

B. Stanaszek, J. Nowakowski, Słownik biograficzny księży diecezji sandomierskiej $X I X-X X$ w., t. 1, Sandomierz 2014. 


\section{Abstract}

Ks. Bogdan Stanaszek

Repression of communist authorities against Rev. Jan

Wiacek, a Radom parish priest

Rev. dr Jan Wiącek (1900-1973) was a cleric of the Sandomierz diocese. Wiącek was a parish priest in Radom for 13 years, and then in Koprzywnica near Sandomierz for another 20 years. He started leading the parish of the Sacred Heart of Jesus in Radom-Glinice in the summer of 1941 under the Nazi occupation. After the war ended, he continued to build the local church. In 1949, Bishop Jan Lorek, the ordinary of the Sandomierz diocese, put him in charge of the parish of the Care of the Blessed Virgin Mary in Radom; Wiącek also served as a dean. It was thanks to him that the parish repaid large pre-war debts. He was first troubled by restrictions on the part of state authorities in 1950. Initially these included financial sanctions (disproportionately high taxes). The authorities also wanted to forcibly accommodate additional tenants in the presbytery. Rev. Wiącek was intimidated, harassed by night phone calls and threatened. The authorities insisted that Wiaccek should join the movement of the so-called "patriotic priests" who supported the government and criticised the Church hierarchy. When he flatly refused, state authorities demanded that he be removed from his position. To this end, they used the decree of 9 February 1953. Bishop Lorek defended Rev. Wiacek by submitting appeals to central authorities. The dispute lasted eight months; faced with pressure, the bishop finally granted Rev. Wiącek a period of leave. In February 1954 he transferred Wiącek to the parish in Koprzywnica. Despite efforts made after the political thaw of late 1956/early 1957, the state authorities did not allow him to return to Radom.
Keywords: repression, communist authorities, Radom parish, Jan Wiącek. 


\section{Abstrakt}

Ks. Bogdan Stanaszek

Represje władz komunistycznych wobec radomskiego

proboszcza ks. Jana Wiacka

Słowa kluczowe: represje, władze komunistyczne, parafia radomska, Jan Wiącek.
Ks. dr Jan Wiącek (1900-1973) był duchownym diecezji sandomierskiej. Przez 13 lat był proboszczem w Radomiu, a następnie przez kolejne 20 lat w Koprzywnicy koło Sandomierza. Proboszczem parafii Najświętszego Serca Jezusowego w Radomiu-Glinicach został w okresie okupacji niemieckiej, latem 1941 r. Po zakończeniu wojny kontynuował budowę tamtejszego kościoła parafialnego. W 1949 r. bp Jan Lorek, ordynariusz diecezji sandomierskiej, mianował go proboszczem eksponowanej parafii Opieki Najświętszej Maryi Panny w Radomiu, pełnił także funkcję dziekana. Jego zasługą było spłacenie sporych, przedwojennych długów parafii. Restrykcje ze strony władz państwowych dotknęły go w 1950 r. Początkowo były to sankcje finansowe (niewspółmiernie wysokie podatki). Władze chciały także przymusowo dokwaterować na plebanię dodatkowych lokatorów. Próbowano go zastraszyć, nękano nocnymi telefonami i pogróżkami. Naciskano, by włączył się w działania ruchu tzw. księży patriotów, wspierających władze państwowe i występujących z krytyką hierarchii kościelnej. Kiedy stanowczo odmówił, władze państwowe zażądały usunięcia go ze stanowiska. Do tego celu wykorzystano dekret z 9 lutego 1953 r. Bp Lorek bronił ks. Wiącka, kierował odwołania do władz centralnych. Spór trwał osiem miesięcy, a w końcu przymuszony hierarcha udzielił ks. Wiąckowi urlopu. W lutym 1954 r. przeniósł go na probostwo w Koprzywnicy. Mimo podejmowanych starań po odwilży politycznej na przełomie 1956 i $1957 \mathrm{r}$. władze państwowe nie dopuściły do jego powrotu do Radomia.

Folia Historica Cracoviensia, t. 23, z. 2 (2017) 